Portland State University

PDXScholar

4-1973

\title{
The grim security of the past: the historiography of Henry Cabot Lodge
}

Claude Singer

Portland State University

Follow this and additional works at: https://pdxscholar.library.pdx.edu/open_access_etds

Part of the Political History Commons, and the United States History Commons Let us know how access to this document benefits you.

Recommended Citation

Singer, Claude, "The grim security of the past: the historiography of Henry Cabot Lodge" (1973).

Dissertations and Theses. Paper 1591.

https://doi.org/10.15760/etd.1590

This Thesis is brought to you for free and open access. It has been accepted for inclusion in Dissertations and Theses by an authorized administrator of PDXScholar. Please contact us if we can make this document more accessible: pdxscholar@pdx.edu. 
AN ABSTRACT OF THE THESIS OF Claude Singer for the Master of Arts in History presented April 13, 1973.

Title: The Grim Security of the Past: The Historiography of Henry Cabot Lodge.

APPROVED BY MEMBERS OF THE THESIS COMMITTEE:

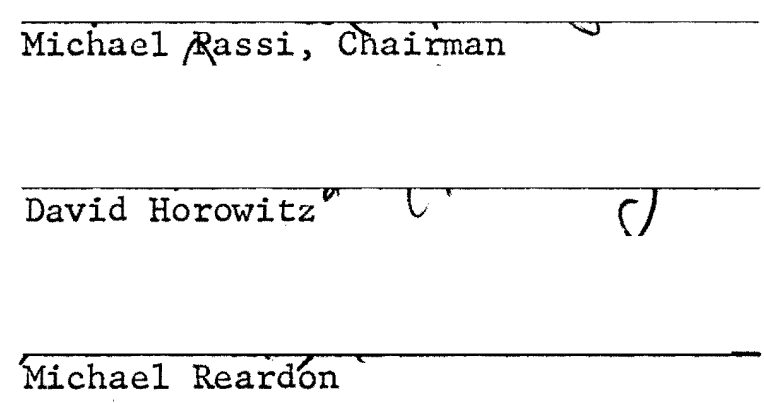

By birth, education, and association, Henry Cabot Lodge belonged to an established New England tradition of attention to history and respect for historical writing. He lived during troubled times, and he realized, as his writings indicate, that America was rapidly changing, that old habits were disappearing, and that powerful new forces were at work in the nation and the world. How Lodge reacted to these circumstances is reflected, in part, in his historical writing. This thesis is an examination of Lodge's historiographic efforts. It is an attempt, through an analysis of style and predominant themes, to describe the cultural values that lie behind simple historical narrative. 
THE GRIM SECURITY OF THE PAST:

THE HISTORIOGRAPHY OF HENRY CABOT LODGE

by

CLAUDE SINGER

A thesis submitted in partial fulfillment of the requirements for the degree of

\author{
MASTER OF ARTS \\ in \\ HISTORY
}

Portland State University.

1973 


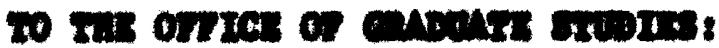

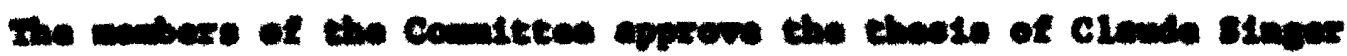
preacented Apre11 13, 1973.

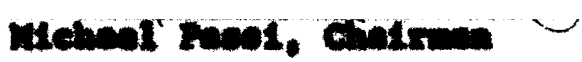

Deviomater

\section{Mand Den}

\begin{abstract}
Angrover

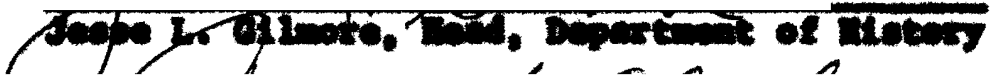

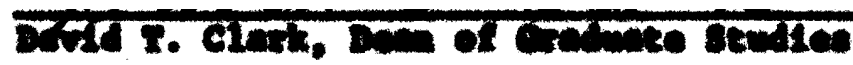

Ame11 13, 1973 
TABLE OF CONTENTS

PAGE

PREFACE

iii

CHAPTER

I INTRODUCTION $\ldots \ldots \ldots \ldots \ldots \ldots \ldots \ldots$

II THE GRIM SECURITY OF THE PAST ......

II THE ELEMENTS OF STYLE $\ldots \ldots \ldots \ldots \ldots \ldots$

IV THE ROMANTIC HERO

$\checkmark$ THE MARCH OF THE RACE

60

vi CONCLUSION $\ldots \ldots \ldots \ldots \ldots \ldots \ldots \ldots$

81

SELECTED BIBLIOGRAPHY

88 


\section{PREFACE}

This exercise in historiography was inspired ("inspired" in the loosest, most secular sense) by David Levin's excellent study of Parkman and the other Romantic historians (History as Romantic Art) and by Richard Hofstadter's The Progressive Historians. In characteristically precise and graceful prose, Hofstadter concluded a career of profound contribution to historical studies by reconsidering the works of America's distinguished professional historians -- Turner, Beard, and Parrington -- "reckoning with my intellectual forebears," he termed it. Rounding out my current studies, I find my attention focused on Henry Cabot Lodge, a man who was, in the writing of history, one of this country's great amateur practitioners.

In a study such as this one, two (seemingly contradictory) guiding principles are held in balance. On one hand, a sense of relativism tempers the critical judgments, so that any statement is made with the understanding that no matter how reasonable it seems now, in so many years it may appear indefensible and even ridiculous. Just as recent philosophers of science have recognized the relativity of physical models, so historians caught up in the fervor of research recognize the vulnerability of their conclusions. On the other hand, there lingers a commitment to objectivity and lurks the 
irrepressible notion that progress in historical methodology is made, that modern techniques are superior to those of the past, that truth has been made more accessible through the use of modern techniques.

These two attitudes, working implicitly in studies of historical writing, forming the basis of the methodology, interacting in every judgment, are the unavoidable expressions of our own scientific and confident and yet humanistic and sceptical age. Hopefully, these two sets of values will, through some dialectical wizardry, direct us to a useful impression of Lodge's historiography and of its meaning.

This study is dedicated to my parents, Leslie and Jacques, and could not have been completed without the valuable assistance of the following band of gamblers and litterati: (In alphabetical order) Kim Bottomly, Susan Chadwick, Sherri Charles, Michael Doyle, Richard Emery, Barry Ernstoff, Justin Foster, and Pamela Greer. I am grateful for the encouraging remarks of Professor Otis Pease, for whose seminar the original paper was composed. And finally, I thank my advisor Professor Michael Passi, who is responsible for whatever coherence and guts the paper has. C.S. 
CHAPTER I

\section{INTRODUCTION}

Historians have concluded that the period of the $1880^{\prime}$ 's and 1890's was a most critical one in America's history. With emphasis varying according to interpretation, this period marked the end of the American frontier, the noisy establishment of industrialism on a European scale, the beginning of the end for one-family farming as the representative way of life. It was an age of gigantic corporations, of organized labor's agony and first successes, of new waves of immigration, of urban ghettos, of corrupt governments. As in other times of such important change, social elites declined, and class-wide and occupation-wide identity crises abounded. Reform politics, imperialism, and racism served as expressions of national hope and as outlets for personal frustration. Complex institutions had interfered with simple functions; strangers had encroached upon old neighborhoods; the machine had entered the garden. As expressed in a variety of ways, the failure of America's mission to the world was widely feared. History, as some historians fondly intone, had caught up with the American nation. One modern scholar, Walter Lafeber, has designated the eighties and nineties not as a watershed but as the 
watershed period in American history, and with that, further generalizations pale in comparison. 1

Assuming the seriousness of the social crisis, it is small wonder that many Americans, when confronted by such momentous change, feared being cut off from the treasured past. Repulsed by the post-Civil War scramble, for wealth and the inhumanity that accompanied it, they longed for the days of diligent toil and simple Christian virtues. They denounced the modern social system; a system that seemed to sanction the survival of the boldest, or the strongest, or the cruelest. Like the champions of industrial progress, they too sensed that America stood facing the dawn of a new era, but they were having trouble adjusting to its early 1ight. Confronted by change, they sought to preserve their fading culture, to prevent it from being shouted down by the stentorian present.

With the appearance of "Old World problems" in the New World, many of those who studied history and pondered the future expressed concern for America's fate. Especially susceptible to fits of gloomy ruminations, it seems, were America's "best people," its aristocrats, those whose ancestors had directed the nation's course but who were themselves powerless to reverse the disturbing social trends. Among the greatest sufferers, moreover, were the writers and politicians (for example, those discussed by Frederic Jaher in Doubters and Dissenters), the intellectuals who 
were stricken by assorted attacks of despondency and fatalism. Disoriented by change, they revealed their fears in visions of the nation and the world laid waste amidst bloody revolution and general holocaust. kFor them, in Jaher's words, innovation seemed cataclysmic. ${ }^{2}$

Like the "elegantly neurotic" grandsons of John Quincy Adams, Henry Cabot Lodge was, by virtue of background and upbringing, a likely candidate for the emotional distresses described by Jaher. ${ }^{3}$. He was well-educated, an ardent student of America's past, and he came from an old and prominent Nery England family. "From his precise Vandyke beard to his clipped Boston accent," writes John Higham, "he was the model of a patrician." 4 But Lodge, despite a noticeable concern for the decadence of his class, seemed eminently well-adjusted. While the turbulent era was making victims of many of his fellow aristocrats, Lodge confidently ran for public office and eventually became a leader in the U.S. Senate. While some of his high-born friends turned away from industrial progress in dismay, Lodge encouraged student audiences at Harvard to become active participants in their society. "Be positive, not negative," Lodge advised. "Be in sympathy with your time and your country." 5 . With the nation beset by serious problems, Lodge intended to work energetically for a stronger, sounder America. Wealth, social standing, and education agreed with him, and he brought to his varied pursuits the bouyant optimism of a successful man. On his mother's side, Lodge could trace the family 
history back to 1700 when the first Cabots came to America from the island of Jersey. They were "a numerous race in the Channel Islands," Lodge noted in a passage on his own "heredity," and "of pure Norman extraction."6 Writing in Early Memories (published in 1913 when he was 63), Lodge recalled his grandfather, Henry Cabot, whom he regarded with awe as a direct link with America's glorious past: "I used to try his patience, I fear, by urging him to tell me how he hid under the sideboard and watched Washington at breakfast with his father when the President stopped at my. great-grandfather's house in Beverly, on his journey through New England in 1789."7 Considering his distinguished lineage, it was perhaps natural that Henry Cabot Lodge should cultivate a lifelong interest in American history.

Studying at Harvard with the class of 1871, Lodge was not an exceptional student, though he did receive fine marks in Henry Adams's history class. Adams advised Lodge to become an historian and accepted him as assistant editor of The North American Review. 8 In 1874 Lodge published his first article in that prestigious journal, and in 1877 Adams secured for him a position as instructor at Harvard, personally guaranteeing to President Eliot the young man's "capacity."

I propose that $M r$. Lodge should have a course in United States history coterminous with mine. His views being federalist and conservative, have as good a right to expression in the college as mine which tend to democracy and radicalism. The clash 
of opinions can hardly fail to stimulate inquiry among the students.9

High esteem for Lodge's talents was not shared by Harvard's students, however, and enrollment in Lodge's class declined from 50 to 3. As his biographer Garraty summed it up, "As a teacher, Lodge was no Henry Adams."10 This apparent failure and the lure of politics eventually caused Lodge to abandon an academic career, and in 1879 he left his post at Harvard to run for the state legislature. But years later, in 1915, as a final profession of confidence in his protegé, Henry Adams walked to Lodge's house and entrusted him with the private edition of The Education of Henry Adams to publish as he saw fit.

Although he no longer pursued a career as full-time scholar, Lodge, in the tradition of the nineteenth-century gentleman, retained an active interest in historical affairs. During a lifetime that included thirty-seven continuous years in Congress, Lodge edited the papers of Alexander Hamilton, wrote three biographies for the American Statesmen Series, served as editor for several historical collections, and published numerous essays and articles on historical subjects. In later years, Lodge edited his extensive correspondence with Theodore Roosevelt, wrote an elegant autobiography, and served (from 1915 to 1924) as president of the Massachusetts Historical Society. "All this work," Maria Helen Winslow (author of Concerning Polly and Concerning Cats) informed the readers of her Iiterary Boston of To-day, indicated "an 
industry and ability beyond the common inheritance of those born in the purple...."11

In an age of Republican domination, Lodge's federalist and conservative interpretation of American history represented the ascendant ideology. Lodge's first book was a study of his great-grandfather, George Cabot, intimate friend of Hamilton, Washington, and John Adams. When he came to write other biographies, he continued to choose subjects in whom he could identify the upright New England virtues he had seen in his great-grandfather. During his lifetime, when foreign blood was threatening to dilute the old native strains, Lodge revived the memory of the racial integrity and superiority of his ancestors and their society. In a time when he and other American statesmen were dallying with dreams of overseas empire, Lodge looked to the past for the archetypes of nationalism and for representatives of the old fighting good humor. He lived in an age of great tension and domestic trauma, of "highstrung activity," as he described it, but he did not of ten lament the passing of the old times, for the American patriarchs survived in the pages of history as inspiration for the modern nation and as models for a future age. His historiography was the work of a man who, despite his love for the America of former times faced the twentieth century declaring, "I am no pessimist. I am an optimist." 12

The foregoing review gives rise to several questions regarding the nature of Lodge's historical writing. First among them concern matters of technique. What kind of 
evidence did Lodge assemble to support his conclusions, what criteria of selection did he customarily employ, and how did his methods differ from those of preceding historians and those of contemporary scholars? How important to Lodge's histories were racial themes, filiopietism, cultural chauvinism, the allure of territorial expansion, and how did Lodge's prejudices affect his evaluation of America's past? At what sort of readers did Lodge direct his historical studies (popular, professional, etc.), and how was his awareness of his audience's tastes and interests. reflected in the style and structure of his narratives?

Other questions arise, these relating more explicitly to the social and intellectual context in which Lodge wrote. Presupposing for the moment an understanding of the attitudes of Lodge's fellow politicians and historians, to what extent did Lodge's historical writing reflect the attitudes of his class? Or shifting the emphasis slightly, to what extent was Lodge reading his own values back into the past and justifying a cultural style to himself and his readers? If Lodge's historiography was part of the venerable New England tradition of attention to historical affairs, how did his writing compare with that of other patrician historians who belonged to the tradition? And how did it differ from the writing of the rising professional group that was developing a new scholarly genre? These questions introduce the general issue of Lodge's view of the purpose of history and the effect his concept of history had on his standards 
of judgment.

The answers to these and related questions would situate Lodge in his society and in the history of American historical writing. Although they cannot all be provided here, the present evaluation of Lodge's writings may contribute to other studies that seek to bridge the gap between our knowledge of nineteenth- and twentieth-century events and our understanding of the cultural context in which they took place. One such study, David Levin"s History as Romantic Art, will serve as a basis for comparing Lodge's writing with the great tradition of nineteenthcentury New England historiography.

It is Levin's thesis that the New England historians were involved in a similar intellectual process as their counterparts in literature and the other arts; that they adapted romantic themes and the vocabulary of contemporary literature to the historical mode; that without belying the standards of historical research they imposed romantic formulas on the historical record; that ultimately, they belonged at the center of the American Renaissance. "They found in romantic conventions," writes Levin in conclusion, "a way of giving the Past artistic order and contemporary moral significance."13

Bancroft, Prescott, Motley, and Parkman shared the conviction that an historian is a man of letters and that the writing of history is properly pursued as an avocation. All four pursued some other "useful" business as well, and 
none, observes Levin, had to write for a living. They were responding to what they considered a patriotic call for a native literature.

Their criteria for selecting proper subjects, like those of a novelist, rested on whether the proposed narrative would be interesting or not. They sought to present grand themes of social morality and human tragedy, and they selected vigorous characters to act them out. The place of action was of ten picturesque scenery, described in such a way as to elicit immediate emotions and to set the proper mood of expectation for the action to come. They believed that an historian can reveal pictorially the character of his subject, that in the portrait of a man lies his essential character. In their elaborate descriptions of historical figures and in their dramatic accounts of historical action, the romantic historians hoped to give their readers the illusion of participation in decisive action and noble affairs.

Among the characteristics outlined by Levin was the romantic historian's belief in progress, in the advance of "natural" forms and institutions and the decline of "artificial" ones. The historian, according to this view, was obliged to recognize the progressive forces in history and to present them in a favorable light. Furthermore, the historian discovered in the unfolding of events timeless moral principles, and he was further obligated to judge men and nations by their specifications. It was according to 
absolute standards of good and evil that Prescott and the others offered their judgments.

Finally, as reflection of both dramatic and moralistic concerns, the romantic historians were prone to create great men, representative men who acted out the drama of progress and who stood for the great moral principles of their age. The romantic historians attributed to their heroes noble qualities, including knowledge of nature's secrets and isolation from ordinary men. Ideally the representative man was, in Levine's words, "the incarnation of the People. He represented national ideals. He acted in the name of the People, and they acted through him. The relationship was emotional, often almost mystical." The perfect hero "suffered for a whole nation," and his suffering enhanced his value as both historical phenomenon and a literary device. 14

These were the prominent features of romantic history, and they are found, though noticeably softened, in the writing of Henry Cabot Lodge as well. Some of the more contrived literary situations, of course were absent from his works, such as those featuring villainous Franciscan monks plotting to undermine state policy. But this should not obscure the fact that certain concerns and attitudes characteristic of romantic historians can be identified in Lodge's writings, and that his overall approach to history bore the heavy intellectual impress of New England's romantic tradition. In the absence here of a systematic comparison of turnof-the-century American historians, it is hoped that a close 
examination of Lodge's writings can offer some insight into the culture of which he was part. "An artist's use of language," wrote the eminent historian F.O. Matthiessen, "is the most sensitive index to cultural history."15 Assuming this dictum suitably applies to historians, then studying Lodge's use of language should reveal certain attitudes and assumptions about his circle of intellectual and political friends as well as those of American society generally. Even a minor representative figure such as Lodge, whose historiographic achievement was relatively undistinguished, articulated the dominant concerns of his culture, explicitly in his opinions and implicitly in his use of language. Nevertheless, using external evidence (political events, for example) only incidentally and concentrating on the historical narratives does create certain technical difficulties. Foremost among them, perhaps, is penetrating the mask of academic language, a manner of expression that serves to disguise a writer's personality. While academic language can mislead the historian by obscuring underlying issues and raising commonplace ideas to levels of distinction, it can never fully hide the assumptions upon which the writing is founded. The formal locutions themselves are indicators of cultural values, and it is less the writer's personality than these standards of taste and judgment which are the subject of this study. Thoroughly scientific, timeless, value-free language does not exist in any writing. The only way to avoid putting forth abstract epistemological assertions, the 
only way to avoid becoming some sort of metaphysician, as E.A. Burtt wisely concludes, is to say nothing. 16

But some language reveals more than others. In cases where academic language or conventional political rhetoric becomes too opaque for service, then other evidence must be marshalled for use. Where one form of textual analysis fails to provide insight, where style is too formalized and mannered to provide clues, then the structure of the narratives, their source materials, and their organizing themes correctly become the object of critical scrutiny. These too, analyzed in the context of Lodge's stated positions, can yield important insights. Fortunately for modern historians, there exists a wealth of biographies and essays and reminiscences that collectively indicate that, whatever trespasses Lodge committed in his lifetime, and whatever was the value of his voluminous utterances, he did not, at least, say nothing. Limiting a study to one source of information, in this case historical publications, has other disadvantages. But once the importance of history to Lodge and his colleagues is established, it can be used as an indispensable clue to culture values. History, after all, was the formal statement of those values, it was the final word of society's educated men, their assessment of the past, their judgment of men. It was presented to stand for all time as vindication or indictment of former generations. For Lodge and his contemporaries history was, in the words of Moses Coit Tyler in 1878, "the act by which the present reviews the past and utters a 
passionless, wise, and final verdict upon it..."17 Participation in such an awesome enterprise could not be taken lightly. Such responsibility could not fall to careless, undignified guardians.

Since history was the last temporal judgment, historians were expected to present themselves with the dignity of judges. Their manner of expression, their writing style, was extremely:- important. Devoid of literary imagination and craftsmanship, history would lose its fascination; without literary flair and a comnitment to stylistic perfection, historians would lose their audience and history its reason for being. A diminished readership meant that the great moral lessons of history would be lost and that the effectiveness of history's final judgment would be diminished. Without a large and attentive audience, history could no longer act as a restraining force, a force for good. Clearly then, the nature of Lodge's style followed from certain presuppositions about the nature of historical truth. When Lodge complained that in his troubled time style was being neglected, he was, in a sense, lamenting the passing of the kind of historical writing he had always known and practiced, a history that was intuitive, didactic, and above all, well-written. Clarity and elegance of style were no longer such important criteria for the professionallyminded new historians who were busy formulating new standards for history. They were establishing a "scientific" history, one that would not necessarily attract a large readership, 
one that would be dedicated, not to the pleasing arrangement of educational stories, but to the accumulation of hard facts.

In contrast, in all of Lodge's historical writing there emerges one overriding commitment -- not to science, but to his country and its culture; one consuming concern -- for the position of America in the hierarchy of nations. Towards America Lodge could never feign scientific impartiality. Abandoning the impersonal stance of a scholar, he periodically adopted the first person when writing of his people... "We" Americans did this, such-and-such misfortunes befell "us," "our" strength lay in these qualities. Lodge was not a disinterested chronicler of events, and his narratives were not sections taken from the total history of mankind. He was an ardent nationalist who also happened to be an historian, and his was a national history.

Perhaps Lodge's close identification with the nation's oldest myths and grandest schemes was the foundation for his nationalism and an inspiration for his optimism. But as an aristocrat facing a newly-risen commercial elite, as an active politician, as a friend of troubled intellectuals, Lodge stood at the focal point of conflicting social forces, and his works reflect the tensions and aspirations of a turbulent society. At a time when history was a vital forum for nationalist sentiment, Lodge established himself as a great patriot, but his histories also provided a means to present opinions on vital issues. As studies of tradition, 
his works are a valuable indicator of the thoughts that had so much to do with how he and his contemporaries acted. 
NOTES

1. Walter Lafeber, The New Empire (Ithaca, 1963), chapter 1. For an earlier expression of the nineties as watershed, see Henry Steele Commager, The American Mind: An Interpretation of American Thought and Culture Since the 1880's. (New Haven, 1950).

2. Frederic Jaher, Doubters and Dissenters: Cataclysmic Thought in America, $1885-1918$ (London: 1964), p. 3 .

3. Michael Doyle referred to the Adams's brothers as "elegantly neurotic" in an unpublished book review. Barbara Solomon's euphemism is "over-refined." See Barbara Solomon, Ancestors and Immigrants: A Changing New England Tradition (Cambridge, 1956).

4. John Higham, Strangers in the Land: Pattems of American Nativism (New York, 1970), p. 96.

5. Henry Cabot Lodge, "Uses and Responsibilities of Leisure," in Modern Eloquence, ed. by Thomas B. Reed (Philadelphia, 1900), p. 785 .

6. Henry Cabot Lodge, Early Memories (New York, 1913), p. 26 .

7. Ibid., P. 41.

8. John Garraty, Henry Cabot Lodge (New York, 1953), p. 29.

9. Henry Adams to Charles Eliot, in Henry Adams and His Friends, ed. by Harold Dean Carter (Boston, 1947), p. 81.

10. Garraty, p! 51.

11. Helen Maria Winslow, Literary Boston of To-Day (Boston, 1903 ), p. 184.

12. Henry Cabot Lodge, A Frontier Town, and Other Essays (New York, 1906), p. 27.

13. David Levin, History as Romantic Art (New York: 1963), p. 229.

14. Ibid., p. 50 .

15. F. O. Matthiessen, American Renaissance: Art and Expression in the Age of Emerson and Whitman (New York, 1941), p. $x v$. 
16. E. A. Burtt, Metaphysical Foundations of Modern Science (New York, 1927), p. 224.

17. Moses Coit Tyler, A History of American Literature (New York, 1962), p. 122 . 


\section{CHAPTER II}

\section{THE GRIM SECURITY OF THE PAST}

Behind the approach to history adopted by Henry Cabot Lodge lay several generations of secular historiography in Western society. Eighteenth-century philosophers, believing the history of mankind to be orderly and intelligible, examined historical documents in order to discover general truths about the nature of man. They widened the geographical and chronological scope of historical studies while at the same time limiting historical explanation to natural sequences of cause and effect. Voltaire's enlargement of the historian's perspective, Hume's denial of objective standards of morality, and Bayle's close attention to individual facts directed later philosophers and historians toward the formulation of historical relativism. Nineteenth-century historians abandoned the search for natural truths and concentrated on individual historical events, each supposed to have an integrity of its own and each warranting investigation in full detail. As the timeless principles of the Enlightenment dissolved in a sea of historical details, historians began once again to reconsider the nature of historical truth itself. They gradually realized that they themselves were situated in time, that their own role in history determines 
their perception of the role of others, and that the product of their research is a mere culture-bound representation of the events of the past. 1

Despite profound developments in contemporary theory, there appeared in Henry Cabot Lodge's writings few serious discussions of historical study. He once remarked that complete understanding of one man's motives cannot be achieved, but he did not extend this line of reasoning to question historical knowledge in general. Indeed, his assorted comments on related issues demonstrate that Lodge believed in the existence of objective truth in human affairs, and that he apparently believed in the capable historian's ability to weigh the evidence and to arrive at a fair representation of that objective truth.

In the chapter of Early Memories devoted to the Civil War era, Lodge recalled the bitter feelings, the patriotic fervor, the nobility and courage of the nation's leaders, and the social turmoil of that faterul time. By the end of the struggle, America had endured tremendous hardships, more perhaps than during any period before or since. And yet the legacy of heroic action, Lodge complained, was a tendency on the part of historians and the general public to gloss over the great issues that had divided the nation and to drown out the real feelings of the war in meaningless praise for all sides. To save the Union, to abolish slavery -these were noble ends, wrote Lodge, not mere abstract calls to glory. "Slavery was a crime against humanity, and it was 
also a huge economic blunder and a social curse. It is well that it was abolished by the hand of war." These were stem judgments, but it was as judge, after all, that Lodge approached his study of the past.

I have wearied of the tone, so familiar of late, that now, fifty years after it all, everybody was right and nobody wrong, that there was no right and wrong about it, and that the thing to do is to pass it over gently and politely with abundant sentiment and meaningless praise for everybody. No good is ever done by falsifying the past. There was a right and a wrong in the Civil War.... it is a deep injury to shirk the truth. 2

Lodge's belief in "a right and a wrong" could not be shaken by the spirit of conciliation, nor by the moral relativism of philosophers, and he hoped that future historians would weigh the evidence and pass swift and certain judgment. This opinion (that historians should align themselves with the righteous causes of the past) was an element of the earlier, romantic tradition. But there was evident in Lodge's histories a modern, "scientific" influence as well. In his history of England's American colonies, Lodge demonstrated an awareness of the necessity, in historical studies, to consider the role of institutions and social practices. Presumably guided by the meticulous scholar Henry Adams, Lodge based his survey of colonial politics on a comprehensive analysis of colonial society. In histories written after he had given up an academic career, however, Lodge abandoned this approach in order to concentrate on single, heroic figures from the nation's past, figures in whom the lofty 
ideals of nineteenth-century historiography could be embodied. In these later histories the attempt to democratize history, to study "the daily life and habits of the people," as he explained it, was largely forsaken. In these works any cont cern for the operative forces in history was sacrificed to the glorification of history's great operators.

These two manners of approaching history never really converged in Lodge's writings. Certain themes overlapped, of course, notably race determinism and nationalism. But though common themes were developed, Lodge wavered between narrow biography and sweeping essay, between hero-worship and an examination of social structures, between a romantic mode and a more "scientific" one, never arriving at a fully synthesized approach to the study of the past. In Lodge's writing, then, were reflected the conceptual and methodological tensions of late nineteenth-century historiography. As the tendency toward professionalism and specialization developed in America, Lodge found himself moving little by little out of the mainstream of modern historical writing. In his early career, Lodge refrained from commenting explicitly on matters regarding the nature of history and its methodological problems. Excepting an occasional statement of purpose (for example, to show "the influence of Hamilton on our history"), he omitted from his narratives any justification for his approach to history. Perhaps this deficiency, if it may be called that, was due in part to the nature of Lodge's work: of all historical forms, 
biography (before the introduction of complex psychological models in the twentieth century) suggested the fewest methodological problems. "With the man whom the world in its vague way has pronounced great," wrote Lodge, "history must reckon."3 one way or another, the writer simply told and suitably embellished the story of a great man's life, and that was that. If the story were told well, and if it presented a defensible version of the truth, then it was good history.

Nevertheless, there are scattered indications that Lodge did, on occasion, step back from his documents and consider the nature of history. In the introduction to André's Joumal (a lavish limited edition of a British officer's war diary), Lodge loosed one of his few challenges to Lord Acton's position as preeminent maker of aphorisms: "A fact is gossip," Lodge wrote, "but two related facts are history...."4 Catchy, but hardly profound, these sentiments were designed more for the entertainment of the 467 privileged holders of the elegant volumes (and the ten owners of those printed on Japanese vellum) than for the instruction of aspiring practitioners of a demanding craft. The romantic story of a young officer -his successes, his conspiracy, exposure, and eventual consignment to the gibbet -- made good reading even for those with only a passing interest in the nation's past:

...the romantic, the picturesque, or the personally tragic incidents of history, while they touch our imazination most keenly, are not as a rule those 
which have had, or... could have had real influence upon the evolution of the race or in the true sense upon the course of history. A fact is gossip, but two related facts are history, and most of the incidents of history which are from their personal, dramatic, or imaginative quality peculiarly interesting are in their essence unluckily unrelated facts. 5

Here, in a desultory manner, Lodge was trying to establish a criterion for selecting historical evidence. He was seeking a means for sorting out irrelevant incidents, those which only: "touch our imagination" and have no real influence on the course of events.

These thoughts, not yet carefully worked out, reflected Lodge's growing interest in the nature of historical studies or his increasingly defensive posture within the discipline. When asked to write an introduction to a series entitled "The History of Nations," Lodge at last availed himself of the opportunity to examine the intricacies of his craft and to respond openly to the contemporary trends in the historical profession.

Lodge opened the essay on "History" by quoting the same fact-gossip maxim which he had used in André's Journal, this time introducing it with, "It has been wisely and wittily said...." It was the author's purpose to assume the casual stance of a sophisticated editor-in-chief: gossip, he mused, is extremely entertaining -- "it helps us to enjoy life and may also teach us to endure it." 6 From that comfortable position he let fall the jibes, the relaxed wisdom, 
and the lightly profound remarks that befit a man of letters called upon to mitigate the rankorous disputes of academia. Referring to Byron, St. Simon, Napoleon, Emerson, Trevelyan, and of course, Dr. Johnson, Lodge addressed the nagging questions of method and purpose in history with the resolute calm of an erudite man.

For Lodge, the wholehearted adoption of "scientific history" did not necessarily represent the most alutary course to follow. In the essay on "History," he defended other, less rigorous forms of history and warned against accepting ("giving way too much to") "the nineteenth-century. contention about scientific history or that other dogma that 'picturesque' history is trivial." Writing after the turn of a new century, : Lodge cast the dark aspersions of obsolescence and of "dogma" on the very techniques that historians had confidently introduced as modern and realistic.

Even history of the gossip variety had redeeming qualities, for aside from "the very real merits of entertainment and instruction," it was still "the foundation of all other history." 7 Its value was further enhanced by the social purpose it served, making its possessor "more desirable to his fellows." That this last, practical consideration had special meaning for Lodge is indicated by the many times he repeated it. He pointed out that the man who knows some history is "a proportionately more agreeable companion." That man, it is echoed later in the essay, has made himself "more attractive to others." It appears that Lodge, Senator 
Lodge the politician, greatly appreciated this socializing function of being conversant with the past.

Citing the "infinite charm" of Herodotus, Walpole, and Franklin, Lodge cautioned historians against discarding these "old writers of tales," these "simple chroniclers and delightfully egotistic diarists." Their disconnected, desultory, unphilosophical history "most of us in our heart of hearts really like better than any other." It would be most unfortunate if history were appropriated by "those modern extremists who would make it as destitute of literary quality as a museum of comparative anatomy." While acknowledging the contribution of scientific techniques to the study of anthropology, psychology, archaeology, and indeed to history itself, Lodge expressed the hope that history would not divest itself of its connection with literature. History must not be reduced to "a sifted dust-heap." 8

While Lodge was casting innuendoes in the direction of competent bores, his books were being roughed up by the eager critics of The American Historical Review. Although they spared no effort in treating Lodge;s works seriously and in paying their respects to the writer's vigorous and even "eloquent" language, these reviewers were markedly condescending in their evaluation of Lodge's scholarship. His books were described as "refreshing" or "charming," but they were drscreatt for lacking proper documentation and for immoderacy and partisanship. One reviewer, for example, praised the essays in A Fighting Frigate for their attractiveness and 
pointed out that Lodge employed a literary form that "real historical scholars" are liable to look upon "with distrust or even contempt." While he expressed sympathy for Lodge's style of presentation, he concluded his own review by censuring Lodge's book as "partizanship, not history."9

But it is not necessary to survey the reviews of Lodge's books to see that he was caught up in the tension between romantic and scientific historiography and that these strained relations paralleled the conflict between learned amateur historians and skilled professionals. This tension was reflected in Lodge's own writing and in the writing of his friend and colleague Theodore Roosevelt who was also striving to legitimize his part-time efforts at writing history. Roosevelt argued that the literary aspects of historical writing must not be neglected, and his reasons were not grounded in mere sentiment for a passing tradition: "No quantity of photographs will ever be equivalent to one Rembrandt," Roosevelt declared, "and the greatest mass of data, although indispensable to the work of a great historian, is in no shape or way a substitute for that work."10 History must lift up the spirits, extend the imagination, and do everything that great art is expected to do. In these terms, Lodge and Roosevelt presented justification for their approach to history, an approach that was being threatened by the growing devotion to scientific techniques, by the establishment of rigorous graduate programs, and by the introduction of specialized fields of study. Lodge believed that, in the final 
analysis, the study of history must yield more than a stack of unreadable monographs. He envisioned a much larger purpose for the study of history, larger and more important even than that ordinarily associated with the arts.

Lodge outlined this great purpose in his essay "History." History, he declared, "ought to give us a theory of the universe, one that will explain man to himself, "one that will tell man not only where he has gone but whither he will go." In expansive prose, Lodge traced the course of civilization and proclaimed the advent of a new era in which steam and electricity placed the whole world within reach of the dominant races. Then in one or two sanguine and almost mystical passages, Lodge turned, not to science, not to psychology, nor even to religion, but to history for the rationalization for existence and for direction in the future:

Can history bring all the periods within the operation of one harmonious $l a w$ and the scope of a single explanation? ....A new period, bringing with it forces and conditions hitherto unknown, confronts modern history. Unless she can bring forth a theory of the universe and of the present and draw aside the veil of the future, then history in its highest sense has failed. 11

And how can failure be avoided? Where should mankind turn for the great solution to its intellectual problems?

The genius who will draw out from the welter of recorded time a theory which will explain to man both himself and his relation to the universe need fear comparison with no other who has ever lived, for he must not only make the great discovery, but he must clothe it in words which will live as 
literature and touch it with an imagination which will reach the heart of humanity and endure like the poetry of those who sang for the people when the world was young. 12

Comparable rhetorical heights were no doubt frequently attained in countless platform appearances by the senator from Massachusetts -- advocate of expansion, fervent AngloSaxonist, and sometime scourge of the foreign-born. In these passages, however, Lodge reached especially high to ascribe meaning to history and prestige to those who hoped to master it. Characteristically, he envisioned one man -- "the genius" -- who might fulfill the mission of history and in so doing, redirect the course of civilization. Turning Lodge's phrase around, then, there would come a time when a great man would reckon with history.

By encouraging historians to search for "one harmonious law," Lodge was sustaining a traditional concept of the use of historical research in the face of the twentieth-century challenge. He was holding on to the view that history could be reduced to one set of principles, one comprehensive theory, that history held the clues to the nature of man and the meaning of his existence. This fantasy (about "a theory of the universe and of life") suggests that Lodge's aversion for modern historical methods was strengthened by his distaste for the mundane purposes for which those methods were employed. Lodge's out-of-date assumption that order exists in the universe reveals the true extent of his alienation from the whole modern concept of history. 
When Lodge discussed the study of history, or referred to it in a speech or essay on other subjects, he often mentioned history's many practical uses. As we have seen, Lodge valued history as wholesome entertainment, and he pointed out that a knowledge of historical events makes a man more agreeable company. In the ringing phrases of his essay on "History," Lodge maintained that history held certain insights which could benefit mankind and redirect the course of civilization. Lodge's hopes for the study of the past did not stop there, however, and he devised other ingenious uses for history as well.

For scholars and philosophers history might someday offer that one unifying theory of man's universe, but for busy Americans of the present, an adequate knowledge of the past provided examples of patriotic conduct and standards for moral behavior. The popular mind had to be filled and stimulated just as did the mind of the nation's intellectuals, and American history satisfied Lodge's criteria for worthwhile intellectual bulk. Those many minds that shy away from commonplace exhortations, Lodge wrote, might readily yield to history's attractive ways. As Lodge himself relied on the past (as represented by his ancestry, his family, and in old age, his memories), so the nation could rely on the noble actions of yesterday's heroes.

As further seriice to America, history promoted "national consciousness," for an appreciation of past struggles bound 
a people together and girded them for action in future struggles. In the awakening of popular interest in history Lodge saw proof of "the abiding sense that a nation has come to its place in the world"13 and confirmation of spiritual strength and intellectual vigor. Even women, long recognized as the transmitters of proper culture in America, seemed interested at last in historical subjects, much to Lodge's surprise and delight.

To suppose that women would easily or at once take interest in the seemingly stem, gray story of state building and war, of law-making and constitutions, stripped as it was in America, of all the glitter and romance and refinement which clung about the history of monarchies and empires to which they had always been accustomed, would have been to expect too much. 14

As perhaps the ultimate inducement to study the past in the age of Horatio Alger and the Robber Barons, Lodge suggested that a receptiveness to history might yield tangible rewards:

Americans have learned that the fields and the woods, the buildings and streets, which have been the scenes of memorable events, have not only inestimable worth historically and sentimentally, but that they are also pecuniarily valuable
any community lucky enough to possess them.

During an age of flagging faith in a just and healthy American society, during a time when the future seemed especially uncertain, Lodge recommended that the American people $100 \mathrm{k}$ to the past for guidance and rejuvenation. In an age of unbriddied quest for wealth, Lodge's encouragement was sweetened 
with the prediction of increased cash benefits for those who followed his advice and studied American history.

But of all the contributions and uses of studying the past, Lodge valued most its capacity for providing something stable and secure in a world of unceasing turmoil. In Early Memories Lodge observed that history held a special attraction for him, that he was "drawn insensibly toward it" from an early age. Some visions of the past came back to him in old age with a certain "dramatic intensity born of the time," while others recreated the "pleasant atmosphere" of earlier times and reminded him of "that sense of quiet and repose which tradition and habit give." There was sadness in his phrases as he reminded himself that a peaceful time once had existed but now had passed away. He clung to the remembrances of old times and old friends, for they were "among the best of possessions which are assured my by the grim security of the past."16 
NOTES

1. See Georg G. Iggers, The German Conception of History

(Middletown, Conn., 1958). Also see the chapter on eighteenth-century philosophy of history in Ernst Cassirer, The Philosophy of the Enlightenment (New York, 1958), Pp. 197-233.

2. Henry Cabot Lodge, Early Memories (New York, 1913), p. 133.

3. Henry Cabot Lodge, George Washington (2 vols.; New York, 1889), I, 5 .

4. Henry Cabot Lodge, ed., André's Journal, 1777-1778 (2 vols.; Cambridge, 1903 ), I, 3 .

5. Ibid., pp. 2-3.

6. Henry Cabot Lodge, "History," reproduced in A Frontier Town, and Other Essays (New York, 1906), p. 87.

7. Ibid.

8. Ibid., p. 106.

9. Frank Marlow Anderson, untitled book review of Lodge's A Fighting Frigate, And Other Essays and Addresses, The American Historical Review, VIII (1902-1903), p. 572. Ancerson continues: "From the purely literary standpoint the book deserves unqualified and unstinted praise. It is a capital illustration of how history may be made attractive and all the more noteworthy because it employs successfully a literary form not much utilized by real historical scholars and one often looked upon by them with distrust and even contempt."

10. Theodore Roosevelt, History as Literature, and Other Essays (Port Washington, ivew York, 1913), p. 7 . Roosevelt will be discussed further in chapter III.

11. Lodge, A Frontier Town, p. 127.

12. Ibid., P. 96.

13. Ibid., p. 213.

14. Ibid., p. 211. 
15. Ibid., p. 213.

16. Lodge, Early Memories, p. 322. 


\section{CHAPTER III}

\section{THE ELEMENTS OF STYLE}

"What have kings that privates have not too," asks Shakespeare's Henry V, "save ceremony...? And what art thou, thou idol ceremony?" Though Henry Cabot Lodge did not openly contemplate the nature of ceremony, it was apparent that he appreciated its influence in history. Lodge recognized, as does a good card player, that how things seem to be is often more important than how they really are. Accordingly, Lodge displayed great interest in dignity and honor and tactfulness in human affairs. It was an interest that, along with a noticeable preoccupation with racial determinism and heroic leaders, largely determined the nature of Lodge's historiography. It was an interest that played a significant role in the development of his writing style as well.

Lodge's standards of judgment included a profound regard for proper behavior, for ceremony, for what he called "the importance of forms." It is frequently stated that George Washington's lasting contribution to the United States was the establishment of worthy precedents for later statesmen to follow. In this opinion Lodge firmly concurred, noting that a "keen sensitiveness to the dignity and perogatives" of his office enabled Washington to perform his duties 
with distinction and civility and that his "dignity and good taste" were of "inestimable value to his country." In Washington, Lodge found a kindred spirit, because Washington too understood that men "are governed largely by impressions." 1

This principle, this awareness of the value of the symbols of respect, played an important part in Lodge's assessment of foreign policy, a realm of action in which appearances count for so much. In long passages on foreign policy, Lodge's phrases reflected a preoccupation with gestures and their meanings, with the formalities of human behavior. In discussing relations among nations, Lodge's vocabulary was laced with words relating to dignity and honor -- "esteem," "defiance," "outrage," "respect," "insult," "indignation," "redress." In all his writings Lodge relied heavily on what he considered "fitting" as a fundamental criterion of historical judgment. Just as his favorite heroes "never violated the rules of the nicest taste" (said of Webster), and just as his nation achieved a position of esteem among the established powers, so Lodge labored in his writing to present himself as a man of distinction, with a sense for what"s "fitting."

The literary tradition in historical studies was one fading aspect of American culture that Lodge hoped to revitalize. Scientific monographs, confidently submitted by professional historians, usually lacked the grace and polish that Lodge admired-in Parkman's histories and in those of 
Lodge's fellow literary historians. A sound and defensible version of historical truth always commanded respectful attention. Yet without the drama and humanity provided by the literary imagination, history could neither fulfill its great purposes nor satisfy Lodge's intellectual and aesthetic sensibilities. His teacher, Henry Adams, had once remarked to Roosevelt that, "Style is after all the salt that keeps alive the savor of the thoughts we would not willingly have die."2 In his own appreciation of fine writing, Lodge turned to Hamilton (for his "pure reasoning and argument"), Parkman (for his "finished and simple style"), Macaulay (for "the sweep of his great narration") and others for inspiration and direction. 3

Lodge earned some measure of critical recognition for the clarity and fluidity of his writing style. Quoted at the end of a collection of Lodge's essays, The Literary Digest commented that, "his language is chaste, his periods are sonorous...." Similarly, after pointing out certain deficiencies in scholarship, The American Historical Review (which regularly reviewed Lodge's publications) acknowledged the attractiveness "from a purely literary standpoint" of Lodge's historiographic efforts. In a review of Lodge's The Story of the Revolution (1898) John Bigelow Jr. reported that "the reader will be charmed by the author's graphic and vigorous, of ten eloquent language." Another reviewer wrote that Lodge's A Frontier Town (1906) "does not pretend to add to the store of human knowledge, but it does present old 
views in a pleasing and attractive form." 4

Naturally enough Lodge suffered occasional lapses, and not all his essays flowed with the smoothness of a gentleman's memoirs. His writing was of ten plagued by excess verbiage, amply illustrated in the following syntactical puzzle :

But in most cases the historical myth is harmless except upon the general consideration that all historical falsehoods are bad, both great and small, but that truth ought to prevail, for, mighty as truth is, the assertion of the motto that it will prevail, however agreeable in theory, is open to some doubt in practice. 5

In some passages Lodge labored to achieve dramatic effects that threatened to violate his chaste language. In others, he fashioned cumbersome metaphors that, like huge dinosaurs, struggled for many sentences against imminent extinction. The opening of Washington's biography suggests a valiant effort to achieve literary immortality:

As certain lilies draw their colors from the subtle qualities of the soil hidden beneath the water upon which they float, so are men profoundly affected by the obscure and insensible influences which surround their childhood and youth. The art of the chemist may discover perhps the secret agent which tints the white flower with blue or pink, but very of ten the elements, which analysis detects, nature alone can combine. 6

But when striving to clip away such flowery excess, Lodge reached an opposite extreme and presented his readership with the following handful of stems: 
The opposition were not convinoed, and the parties came to a deadlock. Hamilton was driven to desperate measures. He had failed to convince, he could not control, he was unable to mangage, there was but one escape, - he negotiated. 7

Lodge was an avowed partisan who brought old debates up to date by joining them with genuine enthusiasm. One of his historical accounts, complained a reviewer, "savors: rather of the forensic than the judicial." Yet the author brought to his narratives an unusual charm and gentility that created an atmosphere of wisdom and restraint. To be sure, he called one French minister a "feather-headed mischiefmaker" and William Giles "a coarse political ruffian," but these infrequent indulgences were carefully spaced and probably designed to relieve the tediun that accompanies many pages of historical narration. Lodge speculated freely, employing numerous "would have's" and "probably's" throughout his explanations, but these opinions suited the informal and non-academic mood the author sought to create. Overall, it can be said that the major problem in Lodge's writing was the presense of inadequately qualified conclusions, but this was more a deficiency of scholarship than of writing style.

Lodge allowed himself to digress freely on a variety of subjects, and in the biography of Washington, for example, he wandered into an historiographic aside, a discussion of Parson Weems's biography, and then pursued an extended apology for Washington's embarrassing practice of keeping slaves. When writing of the savage attacks on William Cobbett that 
appeared in the gazettes of Coobett's time, Lodge inserted this off-hand observation: "Abuse and scurrility are, unfortunately, not wanting to-day in our journals, and in certain semi-civilized regions of the South and west they probably do not fall far behind their predecessors of 1795 in these undesirable qualities." 8 Lodge could not resist including this piece of regional and political chauvinism, but again, the loose structure was consistent with the non-rigorous, quasi-journalistic style of his biographies.

Lodge's use of superlatives and unqualified adverbs (always, never, etc.) knew no limits, and the appearance of "very" marred many promising passages. Washington, for example, sprang from "very typical" Puritan stock, he was "always" an affectionate and dutiful son, he was "constantly" thinking of others, and he was loved by "everyone" who came in close contact with him. These passages might represent popular history operating at its most primitive level, or they might be seen as the product of an atrophied imagination, or they might simply indicate bad editing. What is clear is that Lodge admired Washington and that his admiration could not be contained by standards of scholarship he might otherwise have sought to uphold. Washington was not loved by "everyone" he encountered, but Lodge was unwilling to disguise his adoration by toning down his language.

Another of Lodge's shortcomings as a writer was an inability, as he moved from one great American to another, to think up new ways of praising his subjects. In his 
fascination with the nation's heroes, he endlessly calculated their weight on some imaginary scale of human greatness. Daniel Webster, for example, was "the intellectual equal" of any English statesman, except the eminent Gladstone. Albert Gallatin, though a man of strong character, was not so great as Hamilton "on the scale of ability." These unsophisticated constructions, used to enhance the stature of America's heroes, indicate why so much of Lodge's writing was pronounced pietistic story-telling, and valueless as history.

Lodge's aphorisms and maxims emerge as tarnished period pieces, but that must be expected from a speaker who somberly advised the Harvard class of 1886 to "be positive, not negative."9 Regarding Washington's admirable behavior at the surrender of Yorktown, Lodge mused that, "Fortitude in misfortune is more common than composure in the hour of victory."10 This statement is quite reasonable in comparison with the more puffed-up offering that appeared in an essay on Samuel Adans:

Men constantly err in their friends, but with the curious animal instinct which they have brought with them across uncounted centuries they are, as a rule, fairly correct in recognizing their most dangerous enemies. II

Lodge's friend and fellow historian Theodore Roosevelt was another high born writer whose fundamental allegiance was to a literary and artistic (as distinguished from scientific) history. In some respects, as John Higham has observed, Roosevelt's outlook was realistic and evolutionary. His final 
arbiter, however, was a vigorous intuition rather than a table of statistics:

Students of history feel that complete truthfulness must never be sacrificed to color. In this they are right. They also feel that complete truthfulness is
incompatible with color. In this they are wrong.

In The Winning of the West Theodore Roosevelt strived to achieve this iridescent goal, going directly to primary sources, quoting directly from these materials, footnoting, and supplying appendices (all in accordance with contemporary scientific trends), while at the same time giving full rein to his literary imagination. Lodge's histories, on the other hand, contained fewer of these trappings of the social sciences. Perhaps his prejudices in this matter had been formed by Henry Adams; who in 1910 had informed Lodge of his hostility to footnotes and appendices as "literary blotches."13

In his essay "History as Literature" (1913), Roosevelt advocated a history not professediy utilitarian and only unconsciously didactic. That kind of history, proclaimed Roosevelt, could still be useful, "as is great poetry." It could "thrill the souls of men with stories of strength and craft and daring, and could lift them out of their common selves to the heights of high endeavor."14 According to this criterion, The Winning of the West was one of the great histories of the nineteenth century, for it was nothing less than thrill-packed.

Furguson, conspicuous from his hunting-shirt, rode hither and thither with reckless bravery, his sword in his left hand... While he made his presence known 
by the shrill, earpiercing notes of a silver whistle which he always carried. Whenever the British and Tories charged with the bayonet, the mountaineers were forced back down the hill; but the instant the red lines halted and returned to the summit, the stubborn riflemen followed close behind, and from every tree and boulder continued their irregular and destructive fire... The pealing volleys of musketry at short intervals drowned the incessant clattex of the less noisy but more deadly backwoods rifles. The wild whoops of the mountain men, the cheering of the loyalists, the shouts of the officers, and the cries of the wounded mingled with the reports of the firearms; and shrill above the din rose the calling of the silver whistle.15

This brief comparison with Roosevelt provides a framework for a passing glimpse at Lodge's strengths and shortcomings as a writer. He could not stir the souls of men with stories "of strength and craft and daring" as Roosevelt was abie to do. His biographical sketches, like many of the subjects they portrayed, lacked dramatic flair. When retelling some supposedly humorous anecdotes about America's first president, Lodge felt obliged to catch himself and add, "The wit of the remark is a little cold to-day, but at the moment..." When describing Washington's courageous behavior at the defeat of Braddock, Lodge concluded by adding lamely that "even now it makes the heart beat quicker to think of him amid the smoke and slaughter..." Doesn't it? Iodge was not, in the finest sense, a talented myth-maker, neither was he much of a storytellex. These self-conscious interjections reveal that Lodge himself was not thoroughly comfortable in these roles. If a compeling dramatic style was not Lodge's forte as a writer, it is clear that a pleasant and engaging manner 
was. Without pretense or great affect, Lodge praised the founding fathers and resolved, in his own mind at least, some of their major political squabbles. He communed with his dignified forebears, allowing in the writing process some of their dignity and equability to rub off on himself. The appearance of the words "polished" and "tasteful" and "noble," somehow invested his accounts themselves with these qualities, perhaps because the critic tums to assess the work with these adjectives recently in mind. When Lodge did chose to censure some statesman, or an entire culture, it was with the display of righteous temper that he permitted in Washington and Hamilton and that his readership, in turn, was more liable to tolerate in him.

Some of Lodge's best writing appeared in his autobiography, Early Memories. Here, without having to defer to the canons of scholarship, he could speak of the past with grandfatherly ease. In Lodge!'s recollection of Francis Parkman, for example, theze flowers the true beauty of the New England diarist's art. A fluid style and a leisurely attention to detail create an atmosphere of venerable worth.

I was less than ten years old at the time and I remember seeing, as if it were yesterday, on a brilliant winter's day a man coming up Beacon street, attired in a long overcoat, light in color, and with a fur cap on his head. In each hand he had a heavy cane and, with the aid of his canes, moved with great rapidity, which I suppose is what first arrested my attention. At the lower comer of Beacon Street and Walnut Street, he suddenly stopped, leaned his back against the fence which ran beside the house then, I think, occupied by Mr. Robert Mason, and paused. 
He rested a few minutes and then started again on his canes and rushed off with the same rapidity. 16

Here was a vivid image, masterly presented. Nostalgic, infinitely chaming, and with an unmistakeable air of irrelevancy, here was Lodge at his best.

As a dedicated booster of his nation and people, Lodge was quick to defend American culture against what he consid-:ered European encroachment and criticism.. He wrote several elaborate essays designed to establish the integrity and worth of American cultural expression. One such effort, "The Origins of Certain Americanisms," was a response to popular English ridicule of American speech habits. In the first place, wrote Lodge, Americans no longer use an "I calculate" or an "I guess" at the end of every sentence; the "hard-worked insular humorists" have Ealsely characterized coloquial English in America. Secondly, and this point occupied the body of Lodge's argument, what the English consider perversions of the mother tongue are actually proper usages with long and distinguished histories. With the heavy manner of an insulted pedant, Lodge proceeded to trace the origins of these forms commonly attributed to vulgar American habits. He pointed out that Chaucer had used "I guess" (as meaning to think or suppose) 1ong before any American did, that Carlyle and Dickens were frequent users of the phrase "right good," and that Pope once spoke of three "real good men."17 Lodge's purpose here was to establish the legitimate and even celebrated ancestry of American usages. He was dabbling in the 
history of languages and reinforcing in the process the connection between history and literature. Like a geneologist discovering rich ancestors, Lodge was using history to defend the American language by linking it with the grand tradition of English letters.

In a related article, "Colonial Habits of Mind," Lodge further strengthened American defenses by rejecting even reliance on English tradition as a basis for cultural security. Although England and America share a common language, they need not, Lodge argued, look to one another for cultural values and standards of practice. America must divorce herself from old World "habits of mind" and cast off feelings of inferiority in the face of European culture. 18

In these articles Lodge was doing consciously, explicitly what he did elsewhere in a less direct way: He was establishing the legitimacy and value of attention to literature, extending the influence of American letters in particular, and extending the scope of historical studies and re-emphasizing their connection with literary affairs. Like many other leaders in his age of organized contact sports, Rough Riders, and fear of nation-wide flabbiness, Lodge praised the "savage virtues" that had always been the basis of America's greatness. 19 He too valued the active life, shunned impractical things, and hailed the material accomplishments of a busy America. But Lodge also loved literature and hesitated in his commitment to science. He believed that a great 
nation manifested its greatness in every realm of human activity, that as in times of ancient glory, dominant, vigorous people produced great writers as well as gallant sailors, noble prose as well as dependable tractors. America too must display all the marks of a great civilization.

Thus Lodge served as propagandist for American letters. Iike the romantic historians before him, he echoed the call for a national literature. He realized that cultural dependence makes a sham of political sovereignty, and though he loved English classical literature and took pride in the Anglo-American tradition, he sought to inspire Americans to produce their own distinctive writing. Like the romantic historians, Lodge acknowledged the scholar's responsibility to literary standards, and he hoped to bring to historical studies the felicitous expression of a classically-educated man. His histories were designed as contributions more to literature than to accumulated knowledge about the past, more to the refinement of American letters than to the advancement of objective standards of historical truth. 
NOTES

1. Henry Cabot Lodge, George Washington (2. vols.; Boston, 1897), II, 78.

2. Quoted in John Garraty, Henry Cabot Lodge (New York, 1953), p. 53.

3. Henry Cabot Lodge, "Francis Parkman," Proceedings of the Massachusetts 斑保ical Society (Boston, 1924), pp. 324-32.

4. Unsigned book review, American Historical Review, XII $(1906-1907)$, p. 702 .

5. Henry Cabot Lodge, The Democracy of the Constitution, and Other Addresses (New York, 1915), p. 209.

6. Lodge, George Washington, I, 15.

7. Henry Cabot Lodge, Studies in History (Boston, 1884), p. 152 .

8. Ibid., P. 119 .

9. Henry Cabot Lodge, "Uses and Responsibilities of Leisure," reproduced in Modern Eloquence, ed. by Thomas B. Reed (Philadelphia, 1900), p. 785.

10. Lodge, George Washington, I, 313.

11. Henry Cabot Lodge, A Frontier Town, and Other Essays (New York, 1906), p. 132 .

12. Theodore Roosevelt, History as Literature, and Other Essays (Port Washington, New York, 1913), p. 7 .

13. Henry Adarns to Henry Cabot Lodge, in Henry Adams and His Friends, ed. by Harold Dean Cater (Boston, 1947), p. 693.

14. Roosevelt, History as Literature, p. 19.

15. Theodore Roosevelt, The Winning of the West ( 4 vols.; New York, 1896), II, pp. 339-40. In the first part of this work, entitled "The Spread of English-Speaking Peoples," Roosevelt sets forth his own pre-racist interpretation of history. Roosevelt and Lodge held similar positions on many issues discussed in this study, including the role of the historian, the uses of history, and the significance of breeding in human affairs. 
16. Lodge, "Francis Parkman," p. 321.

17. Lodge, Democracy of the Constitution, p. 249.

18. Ibid., pp. 246-73.

19. Henry Cabot Lodge, A Fighting Frigate, and Other Essays and Addresses (New York, 1902), P. 21. Lodge observed that a distinguished university president had recently warned against the tendency to magnify the savage virtues. To this Lodge replied, "These primary or 'savage' virtues made states and nations possible, and in their very nature are the foundations out of which other virtues have arisen."

For an excellent discussion of the strenuous life, physical culture, and the principles of virility as expressed in America of the 1890's, see the essay entitied "The Reorientation of American Culture in the 1890's," in John Higham, Writing American History, Essays on Modern Scholarship (Bloomington, 1970), pD. 73-102. 
CHAPTER IV

\section{THE ROMANTIC HERO}

An imaginative literary flourish was not one of Lodge's salient attributes as a writer, and the biographies for the American Statesmen Series afforded little opportunity for sinister friars to make furtive entrances. Neither a forbidding Gothic mansion nor a haunted grave-site nor a ruined Grecian temple was ever the focus of Lodge's historical interests. It is clear, however, that for certain other attitudes and interests Lodge was heavily indebted to his romantic predecessors.

One striking similaricy between Lodge and his romantic predecessors was an earnest attention to the details of physiognomy, signaling, in Levin's analysis, a belief that a man's looks bely his true character. This opinion was implicit in Lodge's careful descriptions of hashington, Hamilton, and Webster, whose faces and heads he searched for outward signs of what everyone knew to be their inward natures. Rarely did this quest end in disappointment. Noted statesmen had noble heads and fine, "intellectual".faces; the noses and chins of Puritan leaders mirrored the craggy features of the New England landscape; famous thinkers invariable had voluminous heads. Of all such portraits, however, Lodge's description of Charles Francis Adams best resembles Levin's model of 
pictorial clues to personality. It also most explicitly fixes Lodge, in this minor respect, within the romantic tradition.

His forehead was broad with abundant room behind it, His features were sharply cut, the eye keen, and the jaw...large, square, and strong, giving an impression of a grip like a bulldog. His mouth corresponded to the jaw, not handsome but of straight clear line, and, as Carlyle said of Webster's, 'accurately closed." Altogether his head and face gave an unmistakeable expression of intellectual power, iron will, and calm determination. The outward appearance told the truth. Mr. Adams had all these qualities in a high degree. 1

But the most important and easily-recognized connection between Lodge and his romantic predecessors was the treatment of history's major figures. These historians all engaged in the creation of American heroes, single towering figures who embodied the aspirations of a nation and at the same time shaped them, men who represented a whole continent teeming with courageous and wise people and whose own efforts imbued the actions of their people with courage and wisdom. Iike the creations of many a novelist's imagination, these historical protagonists tended to merge into one identifiable type. Lodge's work, true to a literary tradition to which he was heir, exhibited this same tendency. His central figures, those with whom he was in greatest sympathy, those who played leading roles in the nation's great dramas, merged into a single ideal type.

In the preface to the biography of Hamilton, American Statesmen Series editor John T. Morse announced that he had 
fully anticipated a sympathetic rendering of Hamilton's life. After all, he had asked Lodge to do the biography fully aware that, "if Mr. Lodge was very naturally inclined to make a hero of Hamilton, he at least practiced a strictly intelligent and reasonable worship..."2 Morse himself, it seerns, was much given to classifying historical figures according to their relative "capacity and services." "When we come to make out the list of our statesmen of the first rank," he wrote, "Alexander Hamilton would probably receive at least a plurality of votes for the highest place." (This imaginary ballot excluded, of course, Washington and Iincoln, who stood by themselves "in grand and undisputed isolation.") If Morse was happy with the style and opinions of the biography of Hamilton, he must have been equally pleased with its popular and financial success, for the book reportedly sold 35,000 copies by 1907 .

In its opening sections Lodge virtually exhausted the vocabulary of praise in order to establish Hamilton as a worthy object of his "reasonable worship." Over the course of five glowing introductory pages, Lodge extolled Hamilton's catholic virtues, his "great coolness," his "daring and sagacious genius," his "reckless daring," and his self-confidence and "extraordinary success." As a member of Washington's war-time staff, Hamilton performed duties that "were various and highly responsibie," though all the while the young officer "sighed" to have an independent command in the field. Lodge's Hamilton was precocious and brilliant, "one of the most brilliant men of the day," possessing a mind that was 
"vigorous, original, and well-stored." The dispatches he wrote from headquarters displayed "sagacity, foresight, acuteness, and force," and in them Lodge perceived "the fertility of resource, the vigorous self-confidence, unhesitating decision and undaunted spirit" which would be revealed in due time to the entire nation. ${ }^{3}$

The admirable qualities of Hamilton were, in many respects, undeniably reminiscent of those that Lodge attributed to another of his great subjects, George Washington. Washington too exhibited an "unusual force of will and character." As portrayed by Lodge, Washington was "bold," "keen," "proud," "manly," "calm," and (not surprisingly) "confident" -- all familiar adjectives to readers of Lodge's Alexander Hamilton. To be sure, there were certain characteristics over which the respective patriots maintained an exclusive hold. Each was an individual, and each emerged from Lodge's book with an outline of individual personality intact. Washington, for example, was a "profoundly silent man," hardly attributable to a person of Hamilton's voluble nature. But the similarities between Lodge's Hamilton and Lodge's Washington are unmistakeable. They emerge wherever the laudatory bijoux are set in place, and they sparkle most conspicuously in the company of Thomas Jefferson, for whon Lodge concealed little of his abiding contempt.

In each biography Jefferson was described as a "wailing" dissembler, "carping" on the sidelines while the great statesmen tended to the nation's business. The only mistake 
Washington apparently ever made was asking Jefferson to become his secretary of state.

It was a rare passage in which Lodge mentioned Jefferson in such non-connotative language as "he did this" or "he said that." Jefferson exhibited all the questionable qualities happily absent in Hamilton and Washington. Whereas Hamilton was "consistent, strong, masculine, and logical," Jefferson, in comparison, was "supple, feminine, and illogical to the last degree."4 Whereas Washington was "essentially a fighting man" and Hamilton was "essentially a fighting man," Jefferson, in comparison, was "a lover of peace," a man with "tender feelings," "a sentimentalist pure and simple." While Washington was building a new nation, Jefferson was "writing from Paris in the flippant vein of the fashionable French theorists, and uttering such ineffable nonsense as the famous sentence about 'once every twenty years watering the tree of liberty with the blood of tyrants. "15 Whereas Hamilton "grappled fearlessly" with great problems, Jefferson, with criticisms that would "disgrace a modern school-boy," stood by and raised "a cloud of falsehoods." If Hamilton encountered opposition, "he either rode over it or broke it down." But when Jefferson was met with opposition, "he went round it or undermined it; he was adroit, flexible, and extremely averse to open fighting." 6 Lodge consistently indulged in these easy dualisms whenever Jefferson had the temerity to appear in the same paragraph with the lofty leaders of the federalist presence. As Jefferson came to represent all the nation's 
factious discontent, so Washington and Hamilton, in a mixture of recurring phrases, merged into that single heroic type: "The man of action," "the master builder of states and governments." Washington had saved the American Revolution, and Hamilton had brought stability to the nation's financial affairs. Both men proved themselves worthy objects of what Lodge once termed "the noble instinct of hero-worship."7 Jefferson, meanwhile, was a collection of cultural values and personal qualities that Lodge never hesitated to criticize. To Lodge, steadfast nationalist, advocate of an agressive foreign policy, guardian of a distinctive American culture, Jefferson symbolized all that he detested. Here was a true cosmopolite, a man who "loved France and the ideas of the Revolution" and whose lack of resolution and fortitude had often compromised America's position in the world. Here was a man who "dreaded" war, a strange attitude for the leader of a vigorous young nation. And here was a professed democrat, not a guiding light for his fellow citizens to follow, but a man who payed continual homage to the whims and fashions of the masses. To Lodge, the latter-day heir to the federalist tradition, Jefferson stood for all the forces -- opportunism, political ambition, factionalism -- that served to weaken the foundations of representative government.

But aside from serving as political and cultural whipping-boy in Lodge's narratives, Jefferson served another important purpose as well. As literature, Lodge's histories benefited from the intervention of an evil agent, an 
unscrupulous servant of dark intentions. With the tenure of villainous monks having run out, Jefferson proved an appropriate replacement. Here was a ready foil for the heroic figure, a personality that easily lent itself to invidious contrasts. In this literary function, Jefferson inherited the qualities that were traditionally attributed to the underminers of state policy and to the seekers after political, as opposed to national, fortunes:

But of all the villains and heroes that Lodge selected to portray none was more curious and unlikely than the embattled patriot he presented in Hero Tales from American History. Written with Theodore Roosevelt, this was a collection of short, colorful episodes taken from the nation's past and devised to instill in a wide audience an appreciation of "the heroic virtues"...a sort of prototype Profiles in Courage. Each writer selected a few subjects that would "fasten some feat, some deed, deeply in the memory" of his readers, especially young people. The authors sought to use "simple historic narration" for presenting important moral lessons, and they chose the accomplishments of Washington, Sheridan, Grant and others to convey their message. Amidst tales of military daring and political uprightness, however, the life of the mind did not go unrepresented. In this rather unlikely context, Lodge expressed his profound respect for Francis Parkman and for the tradition Parkman represented. Sandwiched between the stories of John Quincy Adams (venerable Congressman defending free speech in the House) and Davy Crockett 
(facing his foes at the Alamo, "ringed around by the bodies of the men he had slain") appeared Lodge's sketch of the famous literary historian ("of good Puritan stock"), patientIy doing battle with unwieldy documents and recurring sleeplessness. 8 Parkman was himself a kind of romantic hero here, alone, courageous, and faithfully serving the People by representing them in print.

Assuming that Levin's group portrait resembles the nineteenth-century romantic historians, it is clear that Henry Cabot Lodge exhibited many of the same features Levin describes. This is not surprising, given the power and accomplishment of the tradition and given Lodge's personal connections with the historians. Like Prescott, Motley, and Bancroft, Lodge grew up in New England, studied at Harvard, and wrote for The North American Review; with Francis Parkman he was close friends until Parkman's death in 1893. Of course, with the passing of the older generation an effusive emotional response to historical evidence was no longer fashionable. The author of A Short History of the English Colonies in America might have scoffed at the role of imaginative contemplation in his work and turned away chuckling if expected to search agoniz-. ingly his own feelings when confronted by an historical scene. But although moments of being "thrilled," in Levin's phrase, "with the idea of participating in a continuing history" may have been rare, many of Lodge's concerns and standard explanations illustrate his attachment to romantic values and attitudes. 
None of this is designed to imply that romantic historical writing was fatuous and unscholarly and that modern historiography is precise and objective. Anyone who has read Parkman's studies of American Indian tribes recognizes the high level of sophistication that romantic history could attain. (Certainly ample evidence could be cited, on the other hand, to demonstrate the weakness of more recent efforts.) Lodge practiced his craft under the influence of men who had viewed history as the occuaption of erudite gentlemen applying their intuitive powers to create works of literary as well as scholarly worth. But in an age when students of society sought to standardize their work in accordance with strict scientific principles, Locige was naturally influenced by trends toward non-partisan analysis, austerity of language, and detail study of subjects that, by romantic standards, would have been considered hopelessly dull. As admirer of Parkman and student of Henry Adams, Lodge occupied some intellectual middle-ground between romantic enthusiasm and scientific scepticism, between an age of inspiring literature and one of subjugating science.

When he wrote that it is impossible "to determine with perfect accuracy" a man's motives, Lodge was denying full creditility to explanations based on a novelist's intuition as well as co those based on the sharp new standards of the emerging social sciences. But there was one conclusion that these schools of historical studies shared, one that Lodge was always ready to repeat, namely, that an indication of a man's 
capabilities can be gotten from consideration of his racial background. The acceptance of racial explanations was an aspect of romantic historiography that Lodge could comfortably retain in the modern age. 


\section{NOTES}

1. Henry Cabot Lodge, Early Memories (New York, 1913), p. 302 .

2. From the preface by John T. Morse. Henry Cabot Lodge, Alexander Hamilton (New York, 1882), p. vii. In his first book, a study of his great-grandfather, Lodge had openly announced his prejudices in favor of Federalist heroes: "I have endeavored throughout to be scrupulously accurate and fair in all my statements, but I have not sought in treating New England Federalism to write a judicial and impartial history of the country. My object was to present one side, and that the Federalist, in the strongest and clearest light." Henry Cabot Lodge, The Life and Letters of George Cabot (Boston, 1877), p. vi.

3. The foregoing exerpts were culled from Lodge's biography of Alexander Hamilton, cited above.

4. Henry Cabot Lodge, Studies in History (Boston, 1884), p. 148 .

5. Henry Cabot Lodge, George Washington (2 vols.; New York, 1889), II, 27.

6. Ibid., 220. In one instance, at least, Lodge generously attributed Jefferson's shortcomings to foreign influences: "...he had come home badly bitten by many of the wild notions which at that moment pervaded Paris." Lodge, George Washington, II, 221.

7. Ibid., 45 . Another non-Federalist hero, Andrew Jackson, also received rough treatment at Lodge's hands: "Jackson regulating the currency and the finances was like a monkey regulating a watch." Lodge, Studies in History, p. 315.

8. Henry Cabot Lodge and Theodore Roosevelt, Hero Tales from American History (New York, 1895). 
CHAPTER VII

\section{THE MARCH OF THE RACE}

In speeches and historical essays, Henry Cabot Lodge proclaimed himself an active, modern man. He often remarked that things had changed more radically during his lifetime than during entire centuries that had gone before. The advent of steam and electricity had placed "the whole earth so easily within the grasp of the dominant races."I Born at the dawn of a new era, Lodge felt conficient that he could contribute to the further improvement of the condition of mankind. The Civil War had made him "an optimist so far as the United States is concerned." 2 speaking of his country's future, he observed that from the time of the war he had trusted in the ability of the American people to meet any major crisis. Lodge was apparently an unemotional man who prided himself on his practical nature. He was a politician, one who had not permitted his youthful interest in reform to weaken his commitment to the principles of party loyalty. Likewise in the writing of history, Lodge sought to prevent his enthusiasm from betraying the canons of historical objectivity. He frequently expressed a determination not to glorify the past too much, not to distort the truth in favor of perpetuating even the most salubrious myths. He tried to establish 
for all time that history's great men were also mortals. They too laughed and cursed and passed uneventful years at tedious pursuits. There had been no cherry-tree incident in Washington's life as far as responsible historians could tell, and Lodge was ready to heed the story's lesson by not extending the sway of any unsubstantiated rumors. Furthermore, Lodge was aware, as any sensible scholar is, that history has limitations, that historians have much to learn from other disciplines, that there are many answers history can never supply.

It is impossible to determine with perfect accuracy any man's motives in what he says or does. They are so complex, they are so often undefined, even in the mind of the man himself, that no one 3 can pretend to make an absolutely correct analysis. 3

By the time he published Early Memories (1913), Lodge could look back on the nineteenth century with the cool detachment that modernity inevitably affords. His sense of time and his respect for the changes fifty years had wrought accentuated the remoteness of the world in which the great historians Prescott and Motley had written. He could perceive their reaction to eighteenth-century rationalism as only one free from such intellectual determinants could. The wonders of steam and electricity, their effects upon the behavior of men, had separated him, he believed, from the conventions and prejudices of the romantic mentality. 4

One indication that Lodge had brokea: with romantic 
historiography was his study of early American society, his Short History of the English Colonies in America. Published in 1881 (when the author still regarded historical writing as his proper calling), this book is a model of academic historiography and has been praised by professional historians as a real contribution to the field. 5 . The language is clipped and precise. Few incidents received the inflated treatment which customarily marred Lodge's narratives. The Short History was carefully organized, with an analysis of living conditions in each colony following a chronicle of the important political events. The book was amply footnoted, and every other chapter was neatly punctuated with marginal dates to guide the reader. Restrained, avoiding rhetorical bombast, and employing a matter-of-fact attention to detail, Lodge assembled an austere and useful sumnary of American colonial life.

The feature that most clearly sets this book apart from Lodge's other works is its field of interest, the author's selection of topics. In the sections on colonial life, Lodge examined Anerican communities on the eve of the Revolution with what might pass as the trained eye of a social scientist. His concern was for the development of institutions, their nature in 1765 and their origins. He studied the colonial assemblies, trial by jury, the make-up of colonial militias, the influence of churches, and the degree of religious tolerance. He studied slavery, including estimates of slave populations and assessments of slave codes. He sketched the 
social systems of the colonies, seeking to understand the nature of the class structure, the power wielded by the upper classes and the extent to which ordinary men participated in government. He studied marriages, funerals, and popular amusements as well, taking into account ethnic differences in American rituals. And Lodge examined the economic life of each colony, relating the livelihoods of the people to their habits, thoughts, and manners, fully recognizing the determining influence of how resources were utilized.

These interests, and the manner in which they were pursued, distinguished Lodge's Short History from his other works. Where simple stereotypes might have satisfied him, he sought more complex explanations for human behavior, sometimes proffering socio-cultural observations (for example, "slavery made labor a mark of shame"). Where an idealized version of colonial life might have emerged, he presented a balanced picture instead, with poverty, lawiessness, and assorted other hardships figuring prominently in the narrative: Instead of focusing on enlightened, infiuential individuals, Lodge explored the politics of the regular citizenry and relations between the people and the colonial leadership.

Presumably a short story or some other piece of fiction is more revealing of a man's personality and culture than is a scholarly monograph. But Lodge's Short History, however, as non-connotative as its language is, bears the unmistakeable mark of Lodge's personal interests and values. For example 
his abiding concern for propriety in public relations made almost inevitable the appearance of such statements as "the great mass of the white population of Virginia...lacked polish of manner." His scorn for the dissolute Southern aristocracy, his patronizing dismissal of witchcraft and superstition as "popular mental disease," 6 and an attraction for New England values generally were all attitudes that permeated Lodge's historical writing. But the key to his explanations, and perhaps the foundation for all his generalizations was his constant reference to racial characteristics as the ultimate regulator of a communiry's progress. With purity of Anglo-Saxon blood, a people was virtually assured a happy and prosperous future. On the other hand, any town or colony that was comprised of a variety of ethnic strains was destined to suffer all the social problems that have plagued mankind since the creation of city government. Through direct observation and innuendo Lodge rejected the melting-pot as a viable principle of social organization. Common ancestry and language and customs welds a people into a constructive, potent organism. For lodge, this opinion was supported by all the lessons that could be drawn from America's early history. Lodge's reliance on "race" as an explanation for a society's development reflects not only his personal obsession with heredity but his society's growing concern for its changing ethnic composition. It also represents one of the most important links between Lodge's writing and the historiography of his romantic predecessors. 
In reviewing the racial attitudes of Lodge!s times, it should be remembered that a mere century earlier Americans had been an ethnically homogeneous people. Nathan Glazer reports that 91 percent of the population in 1790 could trace its origins to the British Isles, with the remainder being largely Dutch and German. There were almost no Jews or Catholics in America, and a full 82.1 percent of the white population were of English lineage. Immigration did not reach 10,000 persons per year until 1825, and it was not until the $1840^{\prime}$ 's, in Glazer's estimation, that mass immigration became a significant feature of American Iife. 7

After the turn of the century, Americans began to confront the presence of the foreign-born with an eye toward practical solutions of social problems. By the 1920's and $1930^{\prime}$ 's some social and political theorists were viewing America as a vast arena for competing groups in which attachment to organizations (especially primary social groups) was celebrated as the basis for democratic pluralism. At last, educated Americans were seeking to rationalize the existence of "alien" cuitures in their midsts, to legitimize intellectually a disturbing fact of social life. 8

But the native-born people of Lodge's generation faced the impact of mass immigration without the benefit of reassuring political models. They were tied to the old America -- of individual and regional differences within the context of a uniform Anglo-Saxon culture -- and they were not ideologically equipped for its sudden demise. For Lodge and his 
generation, the age of the founding fathers was the only past the United States had. It had not been so long ago that white, Anglo-Saxon Protestants had proclaimed liberty for America and docmocracy for its (white, Anglo-Saxon Protestant) people. When Lodge reminisced about his grandfather, he was thinking about an age, not so removed in time from his own, that seemed shockingly different in culture from his own age.

The results of the 1890 census heightened the concern of many Americans for their country's changing ethnic composition. It was revealed that during the 1880's five and one quarter million immigrants had entered America, and as the number of aliens rose, so increased the fears of native Americans that their land and their culture would soon be overwhelmed.

The high incidence of crime, pauperism, and political unorthodoxy associated with the immigrant masses spurred Americans in growing numbers to support the movement to restrict further immizration. America, it was argued, simply could not accomodate so many millions of "racially" different peoples. With its frontiers vanishing, its cities becoming intolerably crowded, and with familiar patterns of life quickly disappearing, America needed time to make necessary social adjustments, and it needed relief from the pressures that seemed destined to crush its institutions. To the problems that confronted America during the 1880's and 1890's, therefore, the enactment of strict immigration laws was 
thought by many Americans to be an unavoidable response.

With the nation's attention drawn to the immigration issue, Senator Henry Cabor Lodge introduced a bill requiring all prospective citizens to pass a literacy test, and in 1897 Lodge's measure was adopted by both houses of Congress. The literacy bill (vetoed by Cleveland in March) represented the culmiration of the efforts of restrictionist lobbies throughout the country. It also illustrates the great influence enjoyed by those American social scientists, historians, and other educated people who had for years been laying the foundation for a powerful racist ideology.

The American intellectuals who formulated theories of racial differences were influenced by a combination of social and intellectual factors (among the latter, contemporary anthropological theories that suggested the existence of a hierarchy of races and European justifications for imperialism). Recent historical studies by Davis, Saveth, Higham, and Barbara Solomon provide various accounts of these factors and of their increasing importance to social thought in latenineteenth-century America. Among the prominent intellectuals surveyed in Solomon's Ancestors and Immigrants, for example, are James Russell Lowell, Harvard-educated poet, Charles Eliot Norton, well-bred Harvard-educated scholar, and the Harvard-educated grandsons of John Quincy Adams. Each of these men viewed with alam an American society divided between rich and poor, iiterate and illiterate, nativeand foreign-born. They expressed fears for the safety of 
their heritage - the America handed down by their fathers and the racial integrity of its inhabitants. Among Lowell's students was John Fiske, president of the Immigration Restriction of Boston, and according to Solomon, the most important popularizer of the Anglo-Saxon legend. Fiske had identified the dominant Teutonic characteristic of the "English race" as a "rare capacity" to absorb "slightly foreign elements." But Fiske and the others doubted the capacity of even the strongest institutions to educate and to absorb the endless streams of (very) foreign elements who poured into America every year. 9

In the historical profession, there were many distin. guished exponents of the Teutonic ascendancy. American scholars, according to Edward Saveth's American Historians and European Immigrants, believed that, since dispersal of the Aryans led to institutional recapitulation wherever they settled, American institutions were basically Teutonic in origin. Self-government, representative councils, single heads of government, the whole concept of nation-states -- these and other forms of political enlightenment had been brought by the Anglo-Saxons into England, whence they were carried to the shores of Massachusetts. Not only sound political organization but good blood as well was brought to America, for the early New Englanders had inherited the finest racial characteristics of their mighty Teuton forebears. Herbert Baxter Adams (who saw the seeds of American national life sprouting in the forests of Germany), Albert Bushnell Hart (who believed that the Teutonic nature of Anerican institutions should be 
"sharply defined in the minds" of his students), James $k$. Hosmer (who identified Arnerica's preservation with the numerical preponderance of Anglo-Saxon stock), and Moses Coit Tyler (who saw in colonial literature evidence of AngloSaxon vigor and clarity of thought) were among the influential historians who stressed Teutonic origins as the key to America's greatness. 10

Toward century's end, the ideas of historians who chronicled the relentless advance of the Teutonic races were supported by the principles of heredity, newly-applied to the science of mankind. While historians trumpeted the advantages of having Anglo-Saxon forebears, scientists were fiddling with the possibilities of eugenics. The vague cultural definition of race gradually gave way in popularity to a more clearlystated biological one, and ample historical evidence was marshalled to supplement the conclusions of anthropologists and biologists. In retum, American historians could find sufficient scientific evidence to confirm the superiority of the Teutonic races. Thus, bolstered by the findings of scientists in an age of exuberant respect for science, the views of many leading historians developed into a hardened racist ideology. It seemed that history and science had established beyond dispute the'innate, graduated potentialities of the world's races. These findings, reinforced by the prejudices of the times, served to reinforce the prejudices of the times. Like his fellow historians, Henry Cabot Lodge adopted the Teutonic hypothesis as a basis for historical interpretation:. 
On the Senate floor he insisted that each race possessed "an industructible, unconscious inheritance upon which argument has no effect."ll Accordingly, an essential element of Lodge's working vocabulary was the word "race," which he liberally employed in a variety of contexts. In public life, Lodge was a strenuous advocate of immigration restriction and of United States expansion overseas, and his historical writing reflected the acceptance of racial classification that usually accompanied these views. Characteristics commonly regarded as typical of one race or another, the fragile stereotypes of his day, were freely used to decorate and even to provide explanation for the events of his narratives. But unlike Theodore Roosevelt, for example, Lodge never engaged in the formulation of elaborate constructs based on racial differences. He never traced the course of that "march of the race" to which he alluded. He merely mentioned it for purposes of rhetorical embellishment or as an important phenomenon with which everyone was familiar. His racism was mostly implied, and never did enough doubt (about the devel-opment of races) arise to warrant extensive clarification. Since his primary concern was for single, towering historical figures, Lodge's interest in groups of people -- as representatives of cultures, of classes, or of races -- went largely unexplored.

Lodge's favorite use of the word "race" occurred in connection with the New England Puritans and with Englishspeaking peoples in general. Here it was used positively, 
to aid the identification of certain meritorious traits. At times "race" was used as part of a casual expression, with only vague connotations...for example, in "race and creed" in the following passage:

The Puritans were slow to anger, but when aroused by Indian atrocities, they waged war upon the savages with the persistence, the merciless thoroughness, and the calm determination which was peculiar to their race and creed. 12

At other times, the maintenance of racial purity was a significant aspect of America's first European communities, one that he intended explicitly to explore.

In the process of conquering the New World, the Puritans founded a "strong, well-ordered state," and for several generations they "kept their race unmixed and their blood pure." Their "strong pride of race and origin" was termed "one important secret of their success," while elsewhere in the New World, "vice in general increased under the influence of a large immigration." The strong, well-ordered New England governments, administered by thoroughbred Englishmen for the benefit of a homogeneous population, were models of efficiency, stability, and progress. After all, "the sturdy independence of character and love of local self-government" was "innate in the English race." As long as the English race maintained its biological integrity, then, these noble characteristics would be perserved. 13

Thus, describing its "grim persistence," "iron persistence," its "seriousness of mind" and "intensity of purpose," 
Locige ascribed to the English-speaking race the credit for spreading "successful government in its train" and in another context, for perpetuating the typically "well-ordered liberty of the English-speaking race." English race, English-speaking race, the "stern and hardy race" of Puritans -- these were terms proved to be an indispensable point of reference for Lodge's historical perspective. Wherever moral fortitude, aggressiveness, and venerability were extolled, reference to racial influence was likely to appear, carrying with it the full weight of implied explanation for results obtained. It is obvious from these passages that Lodge's use of "race" was not confined to differentiations of skin colors. His term was broad, applying equally well to what modern writers refer to as cultural factors as well as to strictly biological ones. The French, for example, often the object of Lodge's scom for their chaotic political systems, fared especially badly in comparisons of such "racial" dispositions. "How small and contracted France appears, in comparison with this mighty English race, whose intellectual and material progress have gone hand in hand."14 Whereas the English were adventurous and thorough in their enterprizes, the French were narrow-minded and smug and could never penetrate below the mere surface of things, further examples of the "mental deficiency of their cace." "Our success," Lodge proclaimed, "has made visible their own careleseness and stupidity."15

In his praise for the English and his contempt for the French, Lodge was giving vent to reelings of nationalism as 
well as ethnocentricism. His attachment to English culture was partially motivated by confidence in America, whose institurions he considered of predominantly English derivation. In promoting America as the world's citadel of science and vigor, Lodge's manner of speaking was itself an expression of cultural chauvinism, for he combined the elevated terminology of social science ("mental deficiency of their race") with the forceful language of a man of action (their "stupidity"). Instead of boasting crudely of his own nation's material success, Lodge was celebrating the grand achievements of English culture. When "race" stood for culture and nation, then extoliing the virtues of one's race was a means of glorifying one's nation.

Also singled out for invidious comparison was early America's Irish population. Whereas in the Short History most groups received only cursory description ("sober minded" Quakers, "idle and shiftless" free blacks," "thrifty and industrious" Germans), the Irish received careful attention. Seeking to support his judgment that the Irish in colonial Pennsylvania were "as a rule, a very undesirable addition at that period," Lodge offered the following details:

Scarcely more than a third... succeeded as farmers; and they were a hard-drinking, idle, quarrelsome, and disorderly class, always at odds with the government, and did much to give to that government and to the politics the character for weakness and turbulence, which, beginning before the Revolution, has broken out at intervals down to the present day.16 
population, Lodge pointed out that the inmates of Pennsylvania's jails were "almost wholly Irish," with natives and Englishmen numbering no more than one in ten.

Lodge's later writings, however, were less acrimonious in their treatment of the Irish. By 1885 Boston had an Irish mayor and Massachusetts an Irish governor, and Lodge, while socially aloof, was obliged to treat publicly with new constituency, the embodiment of shifting racial patterns. Perhaps Lodge had reconciled himself to the existence of a strong Irish community, and perhaps the influx of Irish no longer posed the greatest threat to New England society. At least the Irish spoke English. There were enough stranger elements entering the country to make the Irish seem less offensive and to keep burning the fires of Lodge's prejudices. While they had received much of the blame, the problem of governing Pennsylvania did not lie solely with the Irish. Rather it was a simple function of race-mixing itself. Lodge condemned the Irish, but it was his larger purpose to demonstrate that the system of extrene tolerance practiced in Pennslyvania was ultimately responsible for the turbulence that plagued the colony. Witchcraft and assorted other superstitions, for example, derived from that "strong infusion of foreign blood." The great mixture of races exacerbated every tendency toward inefficiency and factionalism. The fact that the ingredients for race-mixing were deficient could not be helped. It was the process of race-mixing that was fundamentally at fault, and that could be avoided. 
According to Lodge, the pioneers on the Western frontier displayed the "instincts of all the conquering races." They belonged to the superior race, and in their successful advance across the American continent Lodge saw the workings of natural race propensities. Since brave men were naturally brave and self-reliant people naturally self-reliant, Lodge's thesis about American success in the West was neatly circular: How can one account for their bravery? Well, they were English-speaking people, well-known for their courage. 17

"Pure-blooded American," "splendid stock," "the gifted race," "our race" -- these and similar references to superior strains were common elements of Lodge's descriptions. But again, Lodge used the term "race" very loosely, sometimes several different ways in the same essay. For example, in Washington's biography he referred to Virginians as a race, and then to Washington himself as being "deliberate and conservative after the fashion of his race..." Race of great men? Of presidents? Demonstrating how truly imprecise was his term, Lodge once wrote of an actor named Bernard that "he belonged to the race who live by amusing their fellowbeings." In his catalogue of human types, Lodge even reserved a file for the race of actors. And on one occasion, in an unusual display of humanism, Lodge even made mention of the "human race."

Despite this non-rigorous use of the word "race," it is probable that Lodge commanded what was then considered a 
consistent understanding of the concept "race." For him "race" was that mixture of cultural and biological factors that comprised the salient features of a group of people. Their actions amounted to the constant interplay between these "racial" factors, the personalities of the individuals, and the situation in which they operated. That which pernitted one group to dominate and condemn another to subservience was, in Lodge's scheme of things, the component of respective racial origins.

At least a generation before the students of Herbert Baxter Adams published their book on Anglo-Saxon towns, observes David Levin, American historians were finding the gerns of Western liberty in the customs of Teutonic tribes. 18 Though not supported by the theoretical literature or scientific evidence that later historians could rely on, the romantic historians too, as Levin expresses it, "saw odds in the blood." Their opinions were based mainly on key events in Western history (1588, 1763, 1870, et al), events which confirmed their belief in Teutonic superiority and in the fated world-wide acceptance of free Teutonic institutions.

Henry Cabot Lodge then, viewed as chronological if not intellectual link between romantic and scientific historians, had the benefit of an established tradition of racially-oriented interpretations. During his lifetime, however, the ambigucus xenophobia and relatively innocuous prejudices of troubled Brahmins were transformed into a formidabie racist ideology, fully sustained by the honored social sciences. 
But Lodge's historical writing, despite references to environmental influences here, a mention of the struggle for existence there, was not designed to integrate systematically historical evidence with biological models. Though indicating an acceptance of the Teutonic germ theory and the superiority of Anglo-Saxon races, Lodge's histories did not test racial hypotheses against collected data. Rather they relied on racist assumptions as simple explanatory models, substitutes for the complicated answers to historical questions. In his haphazard introduction of Darwinian phrases and his indiscriminate use of the term "race," Lodge was accepting the conclusions of modern historiography without bothering to adopt the rigorous methods necessary to substantiate them. When his other explanations seemed inadequate, Lodge could always resort to the reliable principles of biological determinism. As the simple stereotypes of Parkman's generation hardened into an intellectual system based on race, the usefulness of such a formidable theory greatiy increased. Not only the question of immigration but other political issues too were infused with arguments founded upon racial classifications. If the most successful governments are Germanic in origin, it was asked, what would become of America under a system of referendum, recall, and other reform measures of dubious hereditary orizin? If America's greanness did lie in the strength of its free institutions and in the purity of its majority race, then wouldn't ay change in the character of these vital components be detrimental to the Anerican political system? 
As theories of race gained wider acceptance, they came to provide a decisive set of standards for the debates of the time. Then, as now, historical and scientific explanations offered by respected intellectuals were inextricably bound up with the political assumptions of ordinary citizens.

It is often stated that in America the writing of history has served as a substitute for the formulation of political theory. As far as racial interpretations of history were concerned, the connection between historical explanations and the apparent rationale for political action was very close. In the historical writing of Henry Cabot Lodge, there was reflected not only a man's personal assessment of foreign peoples but the attitudes of an entire culture as well. In justifying Southern disfranchisement of blacks, expansion into the underdeveloped world, and restriction of undesirable immigrants, America could turn to its writers of history for a reassuring analysis of the historical roles of the races of men. For a standard presentation of such racial justification America could turn, in particular, to Henry Cabot Lodge. 19 
NOTES

1. Henry Cabot Lodge, A Frontier Town, and Other Essays (New York, 1906), p. 110.

2. Henry Cabot Lodge, Early Memories (New York, 1913), p. 126 .

3. Henry Cabot Lodge, Daniel Webster (New York, 1883), p. 321 .

4. Lodge also discussed romanticism and its relation to modern thinking in his essay on "Francis Parkman," in. Proceedings of the Massachusetts Historical Society (Boston, 1924), pP. 321-36.

5. See John Garraty, Henry Cabot Lodge (New York, 1953), p. 52 .

6. Henry Cabot Lodge, A Short History of the English Colonies in America (New York, 1881), p. 434.

7. Nathan Glazer, "The Immigrant Groups and American Culture," The Yale Review, XLVIII (Spring, 1959), pp. 386-7.

8. See Robert Wolff's essay, "Beyond Tolerance," in Robert Paul Wolff, Barrington Moore, Jr., and Herbert Marcuse, A Critique of Pure Tolerance (Boston, 1965).

9. Barbara Solomon, Ancestors and Immigrants: A Changing New England Tradition (Cambridge, 1956).

10. Edward Norman Saveth, American Historians and European Immigrants; 1875-1925 (New York, 1948).

11. Quorted in Saveth, American Historians and European Immigrants, p. 61 .

12. Henry Cabot Lodge, Studies in History (Boston, 1884), p. 28.

13. The foregoing melange of quotations was taken primarily from Lodge's Short History of the English Colonies.

14. Lodge, Studies in History, p. 376.

15. Ibid., P. 368 .

16. Lodge, A Short History, p. 228. 
17. Lodge's explanation for England's successful occupation of the North American continent is most explicitly set forth in his Stucies in History. The argument there, in its emphasis on racial determinants and its naively circular reasoning, parallels the argument of Theodore Roosevelt in The Winning of the West.

18. David Levin, History as Romantic Art (New York, 1959), p. 81 .

19. On March 7, 1900, Lodge argued on the Senate floor in favor of United States annexation of the Philippines. The speech, in which he invoked the lossons of history for support for his position, neatly illustrates Lodge's irrepressible talent for blending nationalism with a facile reading of world history. A characteristic passage: "You can follow the story of political freedom and representative government among the Englishispeaking people back across the centuries until you reach the Teutonic tribes emerging from the forests of Germany and bringing with them forms of local selfgovernment which are repeated to-day in the pure democracies of the New angland town meeting.... There never has been, on the other hand, the slightest indication of any desire for what we call freedom or representative government east of Constantinople." 
CHAPTER VI

CONCLUSION

In 1924, one year before he died, Lodge addressed the Massachusetts Historical Society to commemorate the onehundredth anniversary of Francis Parkman's birth. His remarks on Parkman's achievement included a final, passing commentary on the distinction being made between history as science and history as literature. Reminded of the controversy that had once raged "between realism and romanticism in novels and plays," Lodge rejected such distinctions as "futile." Shakespeare, he told his audience, was both romancer and realist, and the same twofold talents were required of the great historian. Certainly the writing of history demanded a scientific thoroughness of research. But without that "magic touch" of literature, history "would never reach the world at large." It would be "wholly useless for the highest purpose of its being." 1

In 1924 Senator Lodge was grey-haired, articulate, wealthy, and according to critics and admirers, extremely well-read. He was the perfect model, in other words, of all the qualities which are said to accompany dignified old age. During a lifetime's association with historical studies, Lodge had maintained the image of distinguished critic of American scholarship and culture. He had appeared as a man of letters 
quoting Macaulay and Voltaire, as gentleman-scholar editing the correspondences of Alexander Hamilton, as weary autobiographer setting down history in its purest form, history as experienced, history as actually lived.

The image that Lodge projected in his writing corresponded with the image he cultivated in politics and other activities. His attention to writing style well suited a cultured man's care for how he expresses himself, for how his actions are interpreted by others, for how his actions measure up to timeless standards of dignity and propriety. The structure of Lodge's histories, moreover, with their leisurely pace and a tendency to digress, reflected the living style of a careful but easy-going gentleman. His narratives said what they had to say, but not in a manner pressed for time or cramped for space. His flowery sentences, interrupted here and there for the addition of some minor detail, were perfect examples of conspicuous consumption of time and space. They announced that the author was no cheap publicist. hurrying to make his editor's fall advertising list, but rather a responsible scholar taking time off from the routine of business and politics in order to survey the unfolding of events. Just as Lodge's biographies were designed to commend the Anglo-Saxon founders of America, to celebrate good breeding with a toast to its greatest hunan products, so his writing style, which reflected a gentleman's confidence and indulgent care, linked lodge with the culture of the founding fathers. 
For who but a New England gentleman could afford to cultivate the literary imagination that Lodge defended (and exemplified) in his writing? Certainly not impoverished descendants of black slaves, nor "hyphenated Americans" recently arrived, nor the really poor whites in America struggling to turn pidgin. English into an acceptable facsimile of formal speech. Certainly not self-made businessmen, too absorbed in high finance to acquire the polish of higher learning. By upholding the tradition of romantic historiography, Lodge was seeking to maintain the hold of a few, highly educated men on a field of study which was expanding to include all sorts of socially unregistered students. By extending the standards of historiography to include that "magic touch" of literature, Lodge was, in a sense, narrowing the field and making it the property of a more select group. The closer history draws to the physical sciences, the more accessible become its secrets and the more ordinary its practitioners. In Lodge's age of gaudy new wealth, public education for all, and a rising class of respected technicians, literary history was one of the last refuges of the classically educated man.

But Lodge too was the product of his busy age. He too admired its technical achievements and was imbued with its ethic of efficient production. He could not, for example, justify an elegant essay solely on aesthetic grounds but felt compelled to cefer to more practical purposes, to standards of social utility. He could not compliment the work of 
historians without mentioning the usefulness of their product, whether to the tourist trade or to the nation's spiritwal well-being. Thus, Lodge's writing reflected the strains and contradictions of a culture in transition. His inconsistencies were those of a person caught up in the rush of progress, a force which he encouraged and resisted at the same time. He wanted to become a polished stylist, to spin aphorisms and allude to Dr. Johnson, but he sought rationalization for that wish in the crass standards of a businessman's culture. He reached out for a wide audience, hoping to teach and to inspire all Americans, yet he feared being cut of from scholarly respectability by the smart new professional historians who seemed to scom a popular readership. He hoped to master details and to clear away the fog of historical legends, yet his histories staggered under the weight of Lodge's own prejudices and ulterior purposes. They were prone to sweeping generalization, and they lauded heroes in terms that were impossible to verify historically. He believed in democracy, yet his abiding interest in the Napoleonic leader, guiding a factious people, pushed the will of the people far into the background. In an age when Lodge and Roosevelt were trying to put the old fighting spirit back into Americans, Lodge's admiration for the weak and neurotic Francis Parkman was phrased in the same language he used to describe rugged frontiersmen and intrepid generals. He glorified fighting as the foundation of the world's peace and he extolled the "savage virtues" as the foundation of America's greatness. ${ }^{2}$ Yet he 
also abhorred "vulgar" writing, appreciated the beauty of "finely balanced sentences," and derided the taverns of colonial times as "execrable." 3 swagger and gentility, then, must be counted among all the apparently self-contradictory tendencies of Lodge's writing.

But all these themes and mannerisms were presented in the context of an intensely nationalist history. The American nation -- vigorous individuals acting as an unified force -absorbed Lodge's interests and supplied precedents for his opinions. In America's varied past Lodge could find examples of polish and dignity, and he could find inspiring moments of spontaneious daring. One fault lodge could never tolerate was the "colonial habit of mind," the malady commonly found among rich metropolitan classes who vainly struggled to be something other than American. Not being proud of America was for Lodge "a mean and noxious thing."4

When he wrote of America, Lodge often alluded to its democratic institutions, to which he professed complete allegiance. He mocked the Engiish Tories and their fear of the hardy individualism of America's free people. He lauded William Cobbett as the champion of the masses against the aristocracy, as a friend of liberty and good government, and as the true representative of the English common people in a time of great stress. He praised Samuel Adams as "the first man who understood and wielded the force of the people." $5 \mathrm{He}$ mocked the English Tories for their fear of the hardy independence of America's free people. 
But balancing his historical presentation was the profound awareness that an overly-democratic state could exist and could bring America to ruin. In an essay on Caleb Strong he disposed of opponents of the feceralist constitution with thorough and patronizing disdain, for "all thoughtful men were deeply impressed by the absolute necessity of a stronger centralized government." 6 Lodge's essays on Hamilton were sprinkled with references to "the frenzies of the mob" and to the necessity to check the incipient democracy of Hamilton's unsettled time.

No matter how much he celebrated the democratic spirit nor abominated its excesses, Lodge's history was undeniably federalist, conservative, and fundamentally elitist. His selection of subjects, his upraising them to titanic heights, his emphasis on the role played by three or four single great men in American history belie an elitism that no vague reference to democracy could disguise. Momentous events did not occur by chance, nor were they inevitable. It took great men to make them happer.

It was perhaps ironic that Lodge glorified the achievements of the Hamiltonian system and yet was appalled by many of the consequences of centralized, industrialized society. But whatever difficulties Lodge had coming to grips with modern American culture, he could rely on historical studies to bring heroism, elegance, and even reassurance back into modern living. He sought an aphoristic, intuitive, even a poetic kind of historical truth, one that could bring warmth 
to a cold scientific age. In more melancholy moments, the past represented a repository for all the good things in life, here threatened, there destroyed. "We have all the profound consolation of knowing that the past at least is secure. Hope may fade, but the memories we love can never grow dim or be taken from us." 
NOTES

1. Henry Cabot Lodge, "Francis Parkman," Proceedings of the Massachusetts Historical Society, LVIII (1924), p. 324.

2. Henry Cabot Lodge, A Fighting Frigate, and Other Essays and Addresses (New York, 1902), p. 21 . Lodge's martial noises contrasted sharply with the genteel tones of his literary criticism. In an introductory essay to a collection of great writings, for example, he was less the savage agressor and more the conservative guardian of Western culture. Commenting on a passage from Hawthorne, he wrote that its beauty lay in "the simplicity of the language, the balance of the sentences, the reserve, the refinement, and the final imaginative touch in the charming comparison with which the passage ends."

Henry Cabot Lodge, ed., The Best of the World's Classics ( 10 vols.; New York, 1909), p. xxvi.

3. Henry Cabot Lodge, George Washington (2 vols.; New York, 1889), I, 19.

4. Henry Cabot Lodge, Studies in History (Boston, 1884), p. 366. Here Lodge quotes Emerson's injunction, "They who find America insipid, they for whom London and Paris have spoiled their own homes, can be spared to return to those cities."

5. Lodge, Studies in History, p. 161.

6. Ibid., p. 225. 
PRINCIPAL SECONDARY WORKS CONSULTED

Baltzel1, E. Digby. The Protestant Establishment: Aristocracy \&. Caste in America. New York: Random House, 1964.

Benson, Lee. Toward a Scientific Study of History. New York: J. J. Lippencott, 1972.

Cater, Harold Dean. Henry Adams and His Friends. Boston: Houghton Mifflin Company, 1947.

Garraty, Jom Henry Cabot Lodge. New York: Alfred Knopf, 1953.

Glazer, Nathan. "The Immigrant Groups and American Culture." The Yale Review, XIVIII (Spring, 1959), 382-97.

Gossett, Thomas F. Race: The History of an Idea in America. Dallas: Southern Methodist University Press, 1963.

Handin, Oscar. Race and Nationality in American Life. Garden City, New York: Doubleday \& Company, Inc., 1957.

Higham, John, History: The Development of Historical Studies in the United States. Englewood Cliffs, N.J.: Prentice Hall, Inc., 1965.

Higham, John. Strangers in the Land: Patterns of American Nativism, 1860-1925. New Brunswick, iNew Jersey: Rutgers University Press, 1955.

Higham, John. Writing American History: Essays on Modern Scholarship. Bloomington: Indiana University Press, 1970.

Hofstadter, Richard. The Progressive Historians. New York: Random House, 1968.

Jaher, Frederic Cople. Cataclysmic Thought in America, 1885-1918. London: Collier-Macmillan Limited, 1964.

Lafeber, Walter. The New Empire. Ithaca: Cornell University Press, 1963.

Levin, David. History As Romantic Art. New York: Harcourt, Brace \& Worla, Inc., 1959.

Matthiessen, F. O. American Renaissance. London, New York: Oxf̃ord University Press; 1941. 
Noble, David W. Historians Against History: The Frontier Thesis and the National Covenant in American Historical Writini Since 1830. Minneapolis: University of Minnesota Press, 1965.

Noble, David $w$. The Progressive Mind, 1890-1917. Chicago: Rand Mcivally \& Company, 1970.

Parrington, Vernon L. Main Currents in American Thought. New York: Harcourt, Brace and Company, 1927.

Saveth, Ecward Norman, American Historians and European Immigrants: 1875-1925. New York: Columbia University Press, 1948.

Schriftgiesser, Karl. The Gentleman from Massachusetts. Boston: Littie, Brown, and Co., 1944.

Skotheim, Robert Allen. American Intellectual Histories and and Historians. Princeton University Press, 1966.

Solomon, Barbara Miller. Ancestors and Immigrants: A Changing New England Tradition. Cambridge: Harvard University Press, 1956 . 
SELECTED LISE OE LODEE'S PUBIISAED WOKKS

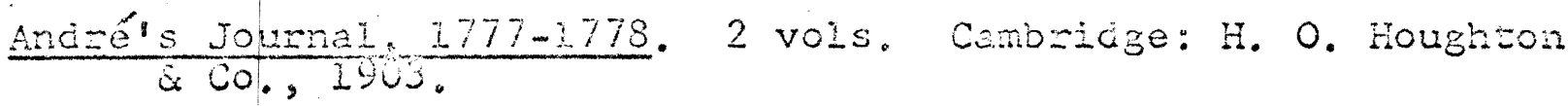
Alexander Hamilicon. New York: Houghton, WEEZin \& Co, 1898. Daniel Webster. New York: Houghton, Miflin \& Co., 1899.

The Democracy of the Conatiention, are othes Adoresses.

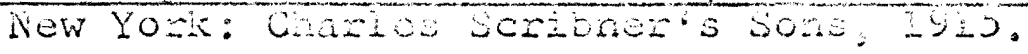

Eariy Menories. New Mork: Chandes Sckibner's Sons, 1913.

A Fighting Frisete, and other Essoys and Aderesses. New Yozk: Chanles seribreris SOns, 1402 .

A Frontier Town and chen assays. Nov York: Charles Scribner's Sons, 2900.

George Washington. 2 vois. Boston: Houghton, Miffiin Co.,

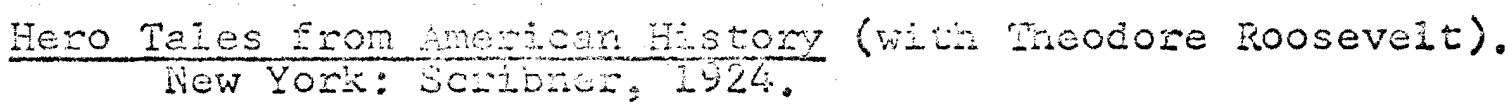

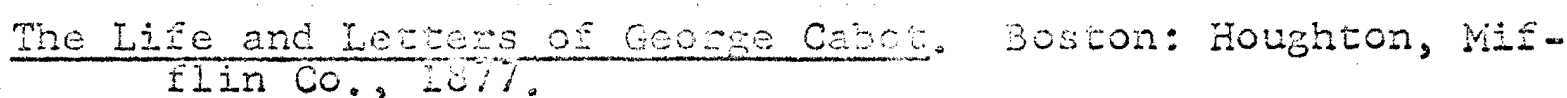

Selections from the cosespondence of weovore Roosevelt and

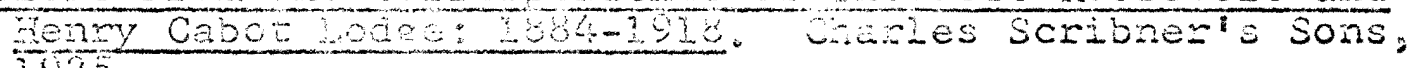
1925 .

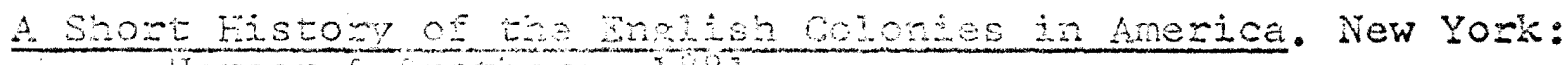
Hatper \& eroters: Iobs.

The Stowy of the revongon. 2 vols. New York: Charles Soribnez: wone: 200.

Studes in Hetomy. Boston, New York: Houghton, Mifflin a Co. 1084 